Clim. Past Discuss., 6, 905-961, 2010 www.clim-past-discuss.net/6/905/2010/ doi:10.5194/cpd-6-905-2010

(c) Author(s) 2010. CC Attribution 3.0 License.
Climate of the Past Discussions

\title{
Do periodic consolidations of Pacific countercurrents trigger global cooling by equatorially symmetric La Niña?
}

\section{J. H. Duke}

CurveWater, LLC 138 Congdon St., Providnece, RI 02906, USA

Received: 10 April 2010 - Accepted: 5 May 2010 - Published: 20 May 2010

Correspondence to: J. H. Duke (john.duke@ @urvewater.com)

Published by Copernicus Publications on behalf of the European Geosciences Union.

Printer-friendly Version

Interactive Discussion

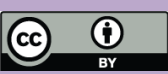




\section{Abstract}

A sporadic phenomenon of internal tide resonance (ITR) in the western equatorial Pacific thermocline is shown to precede 11 of 12 major upturns in the Niño 3.4 index between 1992 and 2008. Observed ITR has up to $9^{\circ} \mathrm{C}$ semidiurnal temperature excur5 sions indicating thermocline heave, but is invisible in time resolution longer than one day. It is independent of westerly wind bursts (WWB). A hypothesis is advanced that (1) ITR dissipates vorticity, leading to Pacific countercurrent consolidation (PCC) by reducing the vortex stretching term in Sverdrup balance. The consequence of lost vorticity survives ephemeral ITR events; (2) The specific surface area of countercurrents is 10 reduced by $\mathrm{PCC}$, which reduces frictional opposition to zonal gradient pressure, which triggers eastward advection at EI Niño onset; (3) PCC also accelerates transfer of potential energy to the "pycnostad" below the Equatorial Undercurrent. This shoals the equatorial thermocline, leading to a distinct mode of equatorially symmetric La Niña (ESLN) characterized by a winter monsoon cell above a "cold eye" that is separated 15 from the South American continent, as in 1998; (4) Precessional southward intertropical convergence zone migration (ITCZ) is an alternate PCC trigger, but its effect is modulated by obliquity; and (5) ESLN causes global cooling in all timescales by (a) reduced Hadley cell water vapor production when its rising branch is above the cold eye, (b) equatorward shift in southern circumpolar westerlies due to Hadley cell constriction, (c) possible $\mathrm{CO}_{2}$ sequestration by increased EUC iron fertilized export production on the equator, and (d) possible adjacent cloud seeding by biogenic dimethyl sulphide. Surprising coincidences of WWB with perigean eclipses suggest a parallel atmospheric tide influence.

Proposed PCC-ESLN forcing operates in multiple timescales, beginning where the 25 annual cycle of strong equinoctial tides coincides with the minimum perigee cycle. This forcing corresponds with El Niño Southern Oscillation (ENSO) events in 1997, 2002, and 2006. Next, extreme central eclipses that perturb perigee-sysygy intervals also correspond with extreme ENSO events, notably in 1877, 1888, and 1982, and a 586
6, 905-961, 2010

\section{Global cooling by equatorially symmetric La Niña \\ J. H. Duke}

\section{Title Page}

Abstract

Introduction

Conclusions

References

Tables

Figures

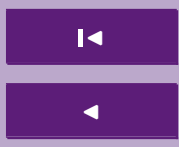

$\Delta$

Back

$\checkmark$

Close

Full Screen / Esc

Printer-friendly Version

Interactive Discussion

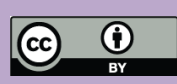


year cycle in the frequency of these eclipses corresponds with known stadial events in the past 4 thousand years. Contrast in the 586 year cycle increases with Earth eccentricity because it is the result of shorter synodic months at aphelion. Longer timescale forcing is by orbital control of the east-central Pacific ITCZ position, yielding a 510 thousand year fast ice sheet melt interval between March and September perihelion. But default ESLN is only interrupted when perihelion in March coincides with rising obliquity. A change in the phase relation between obliquity and precession from 1:2 to $3: 5$ or 2:5 may therefore explain skipped obliquity cycles after the mid-Pleistocene transition. A secular improvement in eclipse commensurability that parallels Cenozoic 10 cooling is noted.

\section{Introduction}

Scientific inquiry into the relation between Earth's orbital and glacial cycles began in the mid-nineteenth century and is reviewed by Berger and Loutre (2004). In the modern era, Hays et al. (1976) confirm the spectral signatures of precession, obliquity, 15 and eccentricity, but the physical mechanism(s) by which the Earth system amplifies these weak signals is not yet established. The early hypothesis of northern hemisphere June insolation forcing is questioned by a "tropical hypothesis" invoking gradient driven moisture transports and EI Niño Southern Oscillation (ENSO) mechanisms, reviewed by Chiang (2009). The problem is enlarged by the later discovery of Dansgaard/Oescher and Heinrich events recurring in 1-2 thousand year (kyr) periods (Clark et al., 1999). Steffensen et al. (2008) observe distinct climate reorganizations in as little as 1 to 3 years at those transitions. So, while Rockström et al. (2009) establish a present anthropogenic climate impact, the baseline from which it must be measured is not straight. Accurate assessment of anthropogenic forcing in future decades will require this knowledge, which is of critical societal importance.

Do observed climate periodicities in different timescales result from a common actuator, diverse independent mechanisms, or complex interactions? The ENSO stands
$6,905-961,2010$

\section{Global cooling by equatorially symmetric La Niña}

J. H. Duke
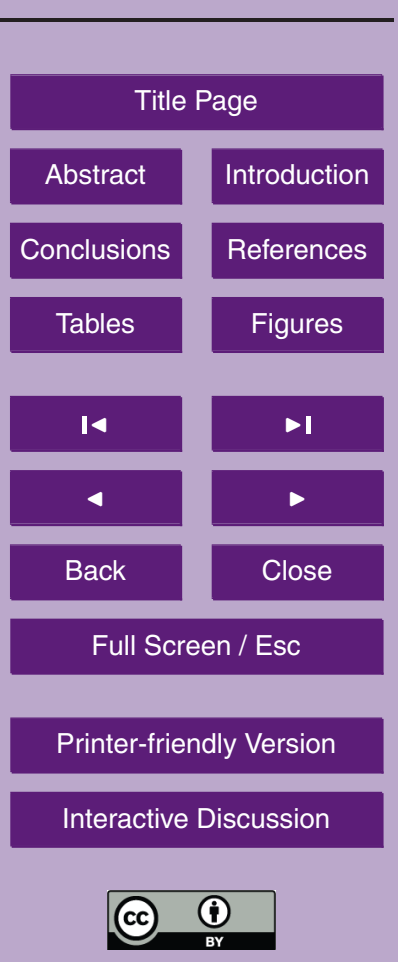
out as the dominant mode of change in the interannual domain, and the particular similarities between ice age and La Niña climates is prominent in the tropical hypothesis (Cane, 1998). In the millennial domain, Clement and Peterson (2008) categorize possible forcing by ocean thermohaline circulation, sea ice feedbacks, and tropical pro5 cesses. An outlier among these ideas is the Keeling and Whorf $(1997,2000)$ proposal that a 1800 year cycle of "repeat coincidences" of maximum tide raising force triggers global cooling through generally increased vertical ocean mixing, citing the non-linear effects of extreme peak tides. Munk et al. (2002) confirmed the prominence of the 1800 year cycle, but question whether its $0.04 \mathrm{~mm}$ tidal amplitude is sufficient to affect 10 global climate. Here I frame a hypothesis related to both tidal and ENSO forcing:

(1) The common mode of global cooling in all Pleistocene timescales is a distinct form of equatorially symmetric La Niña (hereafter ESLN), distinguished from other La Niña by an equatorial "cold eye" centered near $140^{\circ} \mathrm{W}$, with warmer sea surface temperature (SST) farther east;

Tidal climate forcing has been questioned on the grounds that peak tide events are ephemeral (Ray, 2007). But dissipation of vorticity by ITR, however quick, causes permanent transformation of its rotational energy into heat.

ITR is characterized by up to $9^{\circ} \mathrm{C}$ semidiurnal temperature variations in the thermocline, with maximum excursions coincident with local meridian passage of the sun or moon, and synchronous zonal current reversals indicating large scale overturning. It appears qualitatively related to both the phenomenon of "Kelvin fronts" theorized by
$6,905-961,2010$

\section{Global cooling by equatorially symmetric La Niña}

J. H. Duke
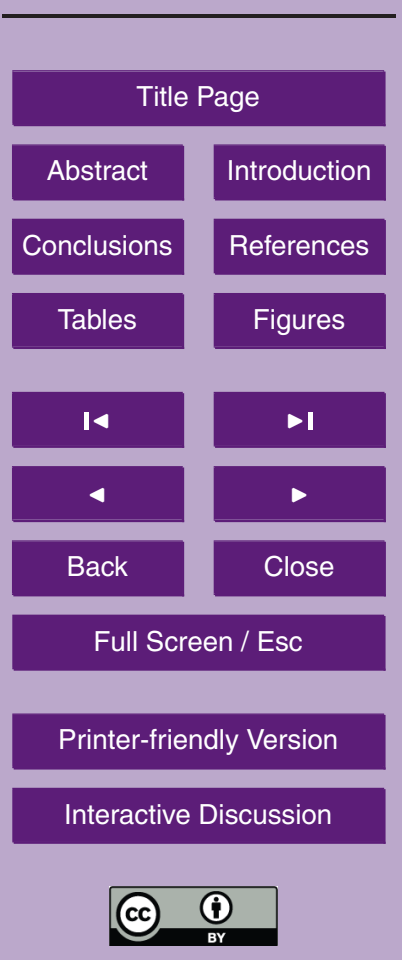
Fedorov and Melville (2000), and internal tides (Garrett and Kunze, 2007). Kelvin fronts form where downwelling equatorial Kelvin waves break due to nonlinearity and shoaling thermocline effects. They propagate eastward and generate attached resonant gravity-inertial waves. Internal tides are baroclinic waves generated by the interaction 5 of barotropic tides with bathymetric features. Their energy may propagate for thousands of kilometers (Ray and Cartwright, 2001), and account for a significant portion of dissipation required to overturn Earth's oceans (Munk and Wunsch, 1998). Adjacent Indonesian Seas (Robertson and Ffield, 2005) and western Pacific bathymetry (Johnston et al., 2003) are potential generation sites, but the observed correspondence with the 10 sun and moon's local meridian passage raises the novel possibility of local generation through interaction with the equatorial pycnocline slope rather than bathymetric slopes. If ITR is some combination of these phenomenon, the gravity-inertial waves trailing a Kelvin front may amplify as ITR when local mixing depresses the buoyancy frequency into the tidal domain of $0.17<\mathrm{N}<0.6$ cycles per hour, as Levine and Boyd (2006) ob15 serve at the Kaena Ridge near Hawaii. Accordingly, observed ITR shows symmetrical temperature excursions 2 to 4 days before and after peak tide events, or at quadrature between them. Intuitively, ITR could also be the non-linearity that initiates Kelvin fronts in the first place. Fedorov and Melville (2000) conclude:

"There is some evidence of rapid temperature changes at the mooring sites of the TAO array (see TAO Web site online at http://www.pmel.noaa.gov/toga-tao) and in the TOPEX/Poseidon data (J. Picaut, personal communication, 1998), which show that the wind-forced Kelvin waves, sometimes associated with the El Niño signal in the eastern Pacific, are clearly fronts rather than linear Kelvin waves. This may necessitate some corrections of the Kelvin wave speed and dissipation rates used in current models of 25 the ENSO. Another important consequence of the study is that nonlinear Kelvin waves may be a source for gravity-inertial waves on the equatorial thermocline. Also, the effect of Kelvin fronts on the mixing processes should be considered."

Cerveny and Shaffer (2001) propose a different means of tidal ENSO forcing in the 18.6 year nodal cycle, in which maximum lunar declination strengthens high latitude
$6,905-961,2010$

\section{Global cooling by equatorially symmetric La Niña}

J. H. Duke

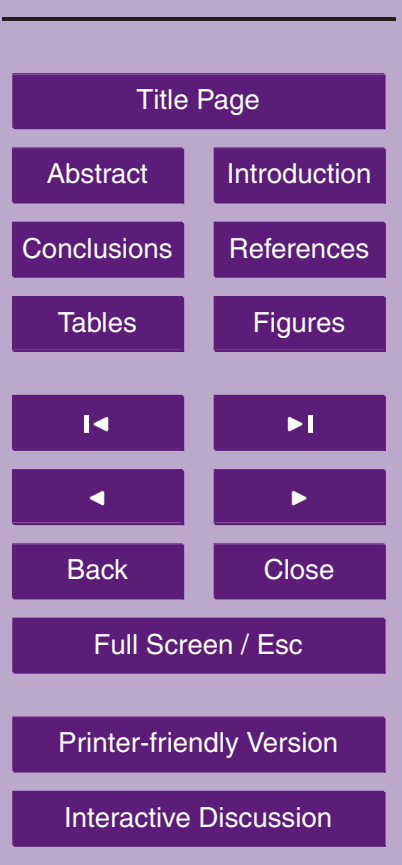


tides, resulting in subtropical gyre acceleration that increases La Niña frequency. In other related research, Treolar (2002) isolates tidal frequencies that correlate with the Southern Oscillation Index (SOI), most prominently to its cold phase, and attributes this correlation to the effect of the moon's nearly coplanar orbit on low latitude phe5 nomena. Ffield and Gordon (1996) find fortnightly and monthly periods in Indonesian Sea temperature that may influence ocean-atmosphere dynamics.

Section 2 presents high resolution Tropical Atmosphere Ocean (TAO) array records which may be examples of what Joël Picaut observed. These sporadic ITR patches coincide with both perigean eclipse events and distinct subsurface current pulses. Sec10 tion 3 describes how ITR may lead to PCC, and Sect. 4 describes the alternate path through which ITCZ migration may lead to PCC. Section 5 then relates PCC to ESLN, and Sect. 6 describes the global cooling potential of ESLN. Section 7 presents short term tidal forcing cycles, and Sect. 8 discusses longer periodicities which may be both tidal and radiative.

\section{ITR Instrument record}

The tidal structure of the equatorial Pacific is relevant to the ITR records presented here. In the dominant M2 constituent, Lyard et al. (2006) show net counterclockwise transport around an amphidrome centered near $16^{\circ} \mathrm{S}, 155^{\circ} \mathrm{W}$, yielding maximum cross equator transport southward near $170^{\circ} \mathrm{E}$ and northward near $130^{\circ} \mathrm{W}$. A low amplitude axis spans the equator along $150^{\circ} \mathrm{E}$.

Fig. 1 presents a first example of ITR at $0^{\circ}, 165^{\circ} \mathrm{E}$ at the spring onset of the major 1997 El Niño. Vertical lines indicate tide maxima at new (N) and full (F) moons, and solar (S) and lunar (L) eclipses. A leading instance of ITR is the 14 to 24 February detail view $(g, h)$, in which vertical lines indicate local meridian passage of the moon (blue) and sun (red). A resonance at $150 \mathrm{~m}$ drives semidiurnal temperature spikes of up to $8^{\circ} \mathrm{C}(\mathrm{h})$ coincident with local meridian passage of both the sun and moon
$6,905-961,2010$

\section{Global cooling by equatorially symmetric La Niña}

J. H. Duke

\section{Title Page}

Abstract

Introduction

Conclusions

References

Tables

Figures

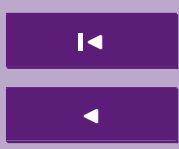

$\Delta$

Back

$\checkmark$

Close

Full Screen / Esc

Printer-friendly Version

Interactive Discussion

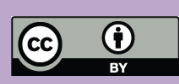


beginning in quadrature. The corresponding one hour resolution zonal currents $(\mathrm{g})$ at $100 \mathrm{~m}$ (solid green) and $150 \mathrm{~m}$ (dashed green) are anti-correlated with each other, with semidiurnal reversals, indicating tidally paced overturning in the thermocline. Another example at 4 to 14 March (i, j) shows subsurface temperature (j) resonance at $175 \mathrm{~m}$.

5 Anti-correlation of $100 \mathrm{~m}$ zonal (green) and meridional (red) currents (i) indicate semidiurnal southwestward tidal pumping. The context of these ITR examples is as follows: A latitude-time plot (Fig. 1a) of 5 day average zonal wind anomaly along $165^{\circ} \mathrm{E}$ shows a westerly wind burst (WWB) centered on the solar eclipse of 9 March; tide height (b) at the Marshall Islands $\left(8.7^{\circ} \mathrm{N}, 167.7^{\circ} \mathrm{E}\right)$ shows the corresponding tide maxima, with no 10 semidiurnal inequality at the equinox; geocentric lunar distance (c) relates perigee to tidal variation, which is highest at the 9 March perigean eclipse; daily subsurface zonal (green) and meridional (red) currents (d), averaged over $30-245 \mathrm{~m}$ with $20^{\circ} \mathrm{C}$ isotherm depth (blue, scale on right), indicate a distinct peak in southward transport two days after the 9 March eclipse, and other southward excursions are near other tidal maxima; a 15 scale-independent measure of ITR (e) plots the daily coefficient of variation (CV = standard deviation/mean) of one hour resolution TAO array temperature at $150 \mathrm{~m}$ depth; one hour resolution temperatures (f) at nine depths are distinguished by the color key shown. The above data spans the formation of the second of two downwelling Kelvin waves known to initiate the record-setting 1997 El Niño (McPhaden, 1999), shown here to have formed in a dissipative context with distinct southward transport at peak tides. Note that ITR beginning 16 February precedes the WWB.

Fig. 2 similarly details a second ITR episode at $0^{\circ}, 165^{\circ} \mathrm{E}$ during the start of the 2002 El Niño (McPhaden, 2004). The 7 to 22 November 2001 detail view (g) indicates semidiurnal resonance at $150 \mathrm{~m}$, and ITR amplitude in December reached $9^{\circ} \mathrm{C}$ within $2512 \mathrm{~h}$, indicated by maximum CV (e) on 22 December. Here the context is a solar eclipse on 14 December 2001 coincident with another WWB (a) and another southward (red) pulse of average subsurface current and a maximum downward $20^{\circ} \mathrm{C}$ isotherm excursion (d) on the same day as the eclipse. This acute example is relevant to differentiating WWB and ITR effects, as both eastward and southward subsurface acceleration
$6,905-961,2010$

\section{Global cooling by equatorially symmetric La Niña}

J. H. Duke

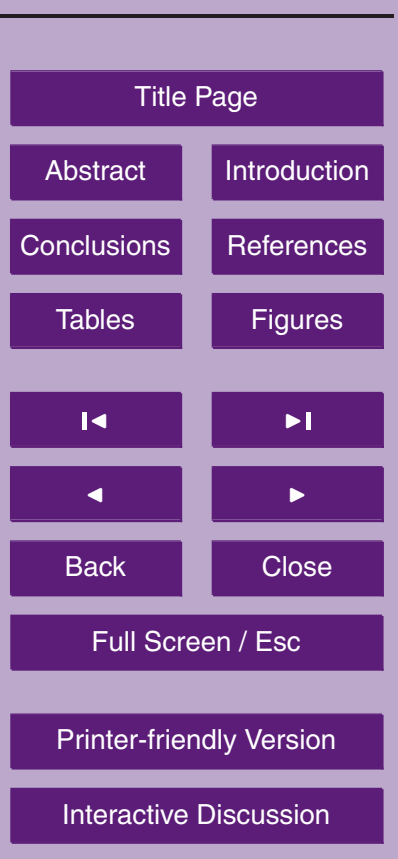


was simultaneous at all depths to $150 \mathrm{~m}$ on the day of the eclipse, but was strongest at $110 \mathrm{~m}$ zonally and at $130 \mathrm{~m}$ meridionally. In contrast, wind forcing alone would be strongest at the surface and propagate downward. The WWB peaked at $11.4 \mathrm{~m} / \mathrm{s}$ one day after the eclipse. Note that tidal range in December 2001 (Fig. 2b) is less than in 5 March 1997 (Fig. 1b) near the equinox.

Given the above illustrations of ITR, Fig. 3 contrasts the weekly 1992-2009 Niño 3.4 index (a) with $150 \mathrm{~m} \mathrm{CV}$ data at $0^{\circ}, 165^{\circ} \mathrm{E}$ (b) and at $2^{\circ} \mathrm{N}, 165^{\circ} \mathrm{E}$ (c). $10 \mathrm{~min}$ data is averaged to $1 \mathrm{~h}$ for consistency. Where data is available, 11 of the 12 most significant positive Niño 3.4 upturns (indicated by red shading) are closely associated 10 with elevated ITR. ITR is particularly strong and persistent in the season prior to the record 1997 event. For comparison, daily zonal wind at $0^{\circ}, 165^{\circ} \mathrm{E}$ (Fig. 3d) also shows many coincidences of WWB with Niño 3.4 upturns, but the late 2005 upturn is notable for its association with ITR but not WWB. Conversely, WWB are often present during declining Niño 3.4, while ITR is less so. Next, Fig. 3e plots 5-day average zonal sur15 face current anomaly within the area $0.5^{\circ} \mathrm{N}-0.5^{\circ} \mathrm{S} \times 170^{\circ} \mathrm{W}-120^{\circ} \mathrm{W}$ (above the EUC core within the Niño 3.4 longitude range). Positive surface current anomalies track the above Niño 3.4 upturns (red shading) that are associated with ITR. In comparison, Fig. $3 f$ shows daily average sub-surface zonal currents averaged over $30-245 \mathrm{~m}$ at $0^{\circ}$, $165^{\circ} \mathrm{E}$ (as in Figs. 1d and $2 \mathrm{~d}$ ), which are more steadily seasonal (Yu and McPhaden, 1999), but with an anomalous maximum in 1998. It is significant that eastward subsurface transport at the equator was greatest in 1998, indicating PCC, even though the El Niño's warm water discharge was a year earlier. Figure $3 g$ is the meridional counterpart, showing other southward subsurface excursions coincident with ITR.

Figures 1 to 3 indicate a correlation of El Niño onset with ITR at $165^{\circ} \mathrm{E}$ which is at 25 least as close as with WWB. There is also evidence of an ITR role in later stages of the ENSO. Figures 4 and 5 provide records of two complete ENSO cycles, respectively November 1996 to March 1999 and November 2001 to July 2003. High resolution sub-surface temperatures are rendered without smoothing, so ITR is coarsely readable by the width of the graphically merged temperature record at each depth.
$6,905-961,2010$

\section{Global cooling by equatorially symmetric La Niña}

J. H. Duke
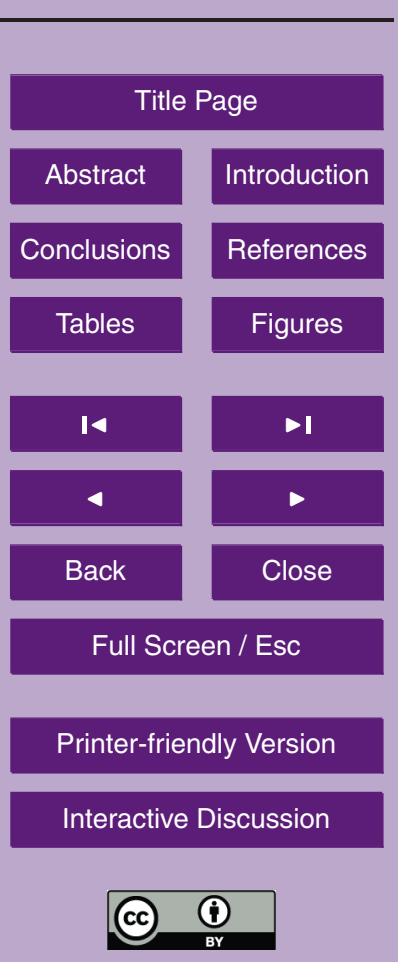
In Fig. $4 \mathrm{~d}$ at $0^{\circ}, 165^{\circ} \mathrm{E}$, the deepest ITR is at $175 \mathrm{~m}$ depth (green) when the pair of downwelling Kelvin waves form in December 1996 and March 1997. McPhaden (1999) shows the thermocline beginning to shoal at $165^{\circ} \mathrm{E}$ in April 1997 immediately after the second Kelvin wave departs eastward. ITR is present throughout this process, work5 ing upwards through successively shallower depths, as ITR at $150 \mathrm{~m}$ (blue) transitions through $125 \mathrm{~m}$ (red) to $100 \mathrm{~m}$ (green again) in June 1997. This of course reflects the shear surface above the EUC shoaling with the thermocline, but note the semidiurnal signature: $125 \mathrm{~m}$ temperature at $0^{\circ}, 165^{\circ} \mathrm{E}$ on 8 May 1997 was $28.9^{\circ} \mathrm{C}$ at $20: 00 \mathrm{UT}$, fell to $20.0^{\circ} \mathrm{C}$, and rose to $29.1^{\circ} \mathrm{C}$ at $08: 00$ UT the next morning. 5-day average isotherms 10 (www.pmel.noaa.gov) indicate that this is an 80-100 $\mathrm{m}$ thermocline heave within $12 \mathrm{~h}$. This progressive upwards mixing continued, reaching $25 \mathrm{~m}$ (green again) in February 1998 . Figure $4 \mathrm{e}$ plots the coincident temperature record at $140^{\circ} \mathrm{W}$, where thermocline shoaling begins in November 1997 (McPhaden, 1999). The same progressive upward ITR mixing is present there, continuing until the record-setting decline in sea 15 surface temperature (SST) in May 1998. This is the context of ESLN emergence discussed in Sect. 5.

Close examination of the lunar distance plot of Fig. 4a shows a secondary cycle in lunar perigee, minimum perigee, designated "proxigee" by Wood (1986), repeating every seventh or eighth anomalistic month (perigee to perigee). Proxigee is on 8 February

in early 1997 and on 28 March in early 1998. Another period of WWB (Fig. 4b) occurs during the September 1997 eclipse cycle. As above, Fig. 4c shows subsurface zonal (green) and meridional (red) currents, and $20^{\circ} \mathrm{C}$ isotherm depth at $0^{\circ}, 165^{\circ} \mathrm{E}$. The correlation of southward with westward transport is evident throughout this interval.

Figure 5 provides a similar record spanning the November 2001-July 2003 ENSO cycle. Most notably, the usual semiannual eastward transport (d, green) at $0^{\circ}, 165^{\circ} \mathrm{E}$ (Yu and McPhaden 1999) is amplified in phase with the four eclipse cycles (recurring every 5 to 6 months) within this interval. Meridional transport (d, red) has clear fortnightly cyclicality in phase with ITR (e) at $200 \mathrm{~m}$ (lower red). Anti correlation of eastward and southward transports may indicate tidal pumping, as in March 1997. This El Niño's
$6,905-961,2010$

\section{Global cooling by equatorially symmetric La Niña}

J. H. Duke

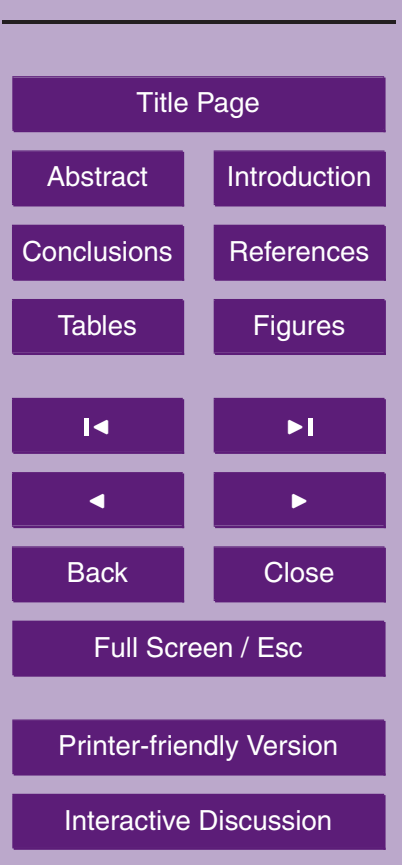


secondary start (McPhaden, 2004) occurs when another southward pulse coincides with the 26 May lunar eclipse. A WWB peaked on 28 June (at $10 \mathrm{~m} / \mathrm{s}$ ), four days after another lunar eclipse. Additionally, Fig. $5 c$ shows close correlation between the weekly Niño 3.4 index and 5-day average surface current above the EUC. Eastward surface 5 transport (Picaut et al., 1996) within this strip indicates PCC discussed below.

Figure 6 provides examples of ITR of with different characteristics in the eastern Pacific that qualitatively resemble Kelvin fronts (Fedorov and Melville, 2000). $10 \mathrm{~min}$ resolution subsurface temperatures at $0^{\circ}, 110^{\circ} \mathrm{W}$ show distinct bursts of turbulence beginning on 15 July 2001 and 7 August 2001. Both occur 3 to 4 days before or after 10 sysygy (new or full moon or eclipse) when meridian passage of the sun and moon are 3 to $4 \mathrm{~h}$ apart, and then dissipate over 4 to 5 days. The detail view of 15 to 17 July shows distinct increases in turbulence at these times, or at their antipodes. Is vorticity conserved in such upheaval? A possible forcing mechanism for these events is a depression of the local buoyancy frequency into the tidal domain. Also, note 5 to $8{ }^{\circ} \mathrm{C}$ 15 declines in $40 \mathrm{~m}$ temperatures within 3 days of the solar eclipse of 5 July 2001 and the new moon of 19 August 2001.

Figure 7 illustrates a last coincidence of WWB and ITR at tidal maxima. Figure 7a shows perigean solar eclipses on 1 July and 31 July that coincide with WWB at $2^{\circ} \mathrm{N}$, $110^{\circ} \mathrm{W}$ (b). The TAO array longitude-time plot along $2^{\circ} \mathrm{N}$ (www.pmel.noaa.gov) indicates that these are the only such WWB in the eastern Pacific in the entire 23 year TAO record. The July solar eclipses bracket the 16 July lunar eclipse, together forming a trio that repeats in the 18.03 year Saros cycle, as discussed below. Therefore the random chance that these WWB and eclipses coincide is very small. Next, subsurface temperatures are plotted at $2^{\circ} \mathrm{N}$ and $95^{\circ} \mathrm{W}$ (c), $110^{\circ} \mathrm{W}$ (d), $125^{\circ} \mathrm{W}$ (e), $140^{\circ} \mathrm{W}$ (f), $155^{\circ} \mathrm{W}(\mathrm{g})$, and $180^{\circ}(\mathrm{h})$. There is a simultaneous abrupt thermocline depression at both $95^{\circ} \mathrm{W}$ and $110^{\circ} \mathrm{W}$ centered on the 1 July eclipse, but the WWB was only present near the later. The sun transited $112^{\circ} \mathrm{W}$ at the time of day of this eclipse. Also, another abrupt thermocline depression at $125^{\circ} \mathrm{W}$ is coincident with the 31 July eclipse, after which the apparent level of mixing energy remained high. This location is where equatorial tidal
6, 905-961, 2010

\section{Global cooling by equatorially symmetric La Niña}

J. H. Duke

\section{Title Page}

Abstract

Introduction

Conclusions

Tables References Figures

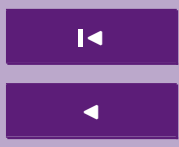
$\Delta$

Back Close Full Screen / Esc

Printer-friendly Version

Interactive Discussion

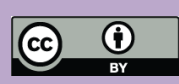


power east of the mid-Pacific amphidrome is strongest (Lyard et al., 2006). The further western records are provided for context.

The above three-way correlations of peak tides, ITR and WWB raise a question, can WWB be a phenomenon of atmospheric tide (Lindzen, 1979; Platzman, 1988)? Does 5 the convectively "tippy" atmosphere of the western equatorial Pacific (Pierrehumbert, 2000) make this possible? Is the related Madden Julien Oscillation (MJO) actually a fortnightly 30 or 45 or 60 day oscillation? Or is MJO a secondary consequence of tidal SST influence (Ffield and Gordon, 1996)? ITR is clearly tidal by its semi-diurnal frequency, and not initiated by WWB because it sometimes occurs in the absence 10 of WWB. The consequence of ITR described below is similar to that of WWB, so it is possible that a mistaken presumption of inviscid vortex stretching has led to empirically overestimated WWB drag coefficients. The non-uniform role of WWB in Kelvin wave forcing (Fedorov, 2002) may in part reflect common causation by tide. Figure 3d shows an interannual variation in WWB, with high frequency in 1993-1993, 1997, 2001-2002, and 2006 that roughly follows a cycle in western Pacific tidal strength described in Sect. 7. The boreal spring prevalence of MJO activity (Hendon et al., 2007; Tang and $\mathrm{Yu}, 2008)$ could reflect equinoctial tide maxima as well as trade wind minima. This conjecture is noted, but will be addressed elsewhere, with possible relevance to cyclogenesis.

20 To summarize the above instrument record, there is a distinct association of ITR with El Niño onset (Fig. 3). Examples of ITR are integral to both Kelvin wave formation (Figs. 1 and 2) and thermocline shoaling (Figs. 4 and 5). Both southward and eastward subsurface transports strengthen at tidal maxima. Some examples of ITR are independent of WWB. In a study of shear turbulence in the EUC, Gregg et al. (1985) conclude, 25 "Mixing in this zone resembles a sharply tuned harmonic oscillator, which can have large output changes for small forcing perturbations."
$6,905-961,2010$

\section{Global cooling by equatorially symmetric La Niña}

J. H. Duke

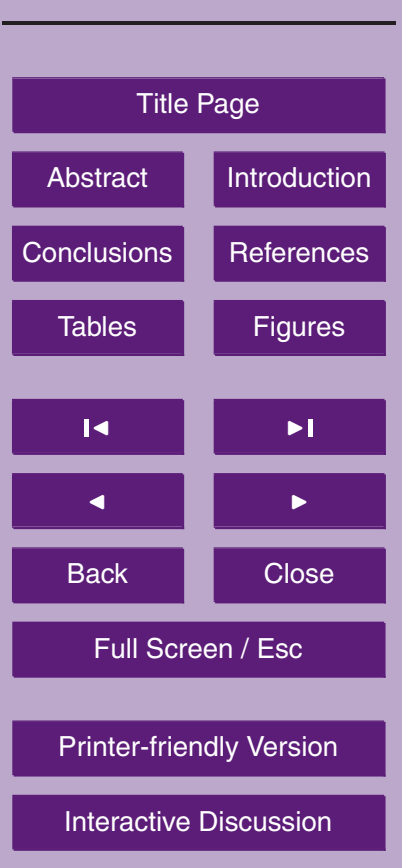




\section{PCC by ITR}

Sverdrup (1947) explains that the extent of the NECC's northward excursion results from a balance between equatorward geostrophic impulse, poleward Ekman impulse, and poleward reaction to vortex stretching by positive wind curl north of the equa5 tor. Discovery of the Pacific EUC in 1952 was five years later (McPhaden, 1986). Johnson et al. (2002) now show the EUC connected to the both the NECC and the south equatorial countercurrent (SECC) within the thermocline at $165^{\circ} \mathrm{E}$. Therefore, at their outset the countercurrents form a continuous ribbon of eastward transport whose edges breach the surface. This ribbon drifts slowly north as the SECC fades, while the 10 EUC and NECC remain connected to $155^{\circ} \mathrm{W}$. In the present hypothesis, friction in the shear layers above and below this ribbon slows the warm pool's eastward release of gravitational potential, just as narrowing the Indonesian Thoroughfare 3 million years ago (Ma) slowed its westward release (Cane and Molnar, 2001). This expanse of friction is normally over $900 \mathrm{~km}$ wide. This hydraulic model of ENSO provides an external 15 forcing mechanism that compliments the recharge/discharge oscillator of Jin (1997a, b).

ITR may trigger PCC by dissipating cyclonic vorticity, which tips Sverdrup balance towards convergence, so the ribbon becomes a pipe, or at least its upper shear surface is eliminated. Physically, extreme thermocline heaving in ITR may dissipate vorticity by

forcing vertical motion that rotating bodies resist (by the Taylor-Proudman theorem), resulting in non-linear increases in friction (as rocking a toy gyroscope quickly brings it to rest by increasing its bearing loads). Unknown to Sverdrup in 1947, non-wind forced cyclonic vorticity also results from shear between the EUC and the opposing South Equatorial Current (SEC), as well as adjacent thinner and slower portions of the countercurrent ribbon. In a study designed to isolate advection and friction effects, Kessler et al. (2003) deduce friction concentrated between $2^{\circ} \mathrm{N}$ and $2^{\circ} \mathrm{S}$, which would tend to reduce positive relative vorticity along the EUC. This is where the proposed ITR
$6,905-961,2010$

\section{Global cooling by equatorially symmetric La Niña \\ J. H. Duke}

\section{Title Page}

Abstract

Introduction

Conclusions

Tables

References

Figures

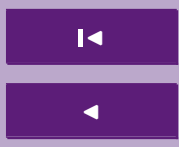

$\Delta$

Back

$\checkmark$

Close

Full Screen / Esc

Printer-friendly Version

Interactive Discussion

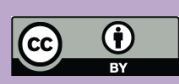


effect is concentrated. Brown and Fedorov (2010) similarly conclude that the classical presumption of linear friction-free Sverdrup balance is not consistent with observations.

Additionally, possible southwestward tidal pumping (Figs. 1 and 5) may indicate an ITR role in entrainment of mean southward tidal transport in the western Pacific (Lyard 5 et al., 2006). In the manor that backwash is reduced on a cobblestone beach, tidal wave passage through ITR would reduce ebb with respect to flood. The resulting accretion of warm surface water could contribute to thermocline depression in the downwelling Kelvin wave formation.

Figure 8 relates PCC to the ITR record of Fig. 3, contrasting the weekly Niño 3.4 10 index (a) with latitude-time plots of surface currents along $165^{\circ} \mathrm{E}$ (b) and $140^{\circ} \mathrm{W}$ (c). Vertical gridlines are at the March equinox. The NECC usually disappears in April at $165^{\circ} \mathrm{E}$ when western Pacific trade winds swing towards the south, and the SECC lapses in September when they swing towards the north. Given this climatology, the $165^{\circ} \mathrm{E}$ plot (b) clearly shows PCC in El Niño years, when eastward surface advection 15 on the equator (Picaut et al., 1996) merges with the NECC. At $140^{\circ} \mathrm{W}$ (c) only the NECC survives. Figure $8 d$ then contrasts the corresponding 90 -day running averages of subsurface transports at $165^{\circ} \mathrm{E}$ (per Fig. $3 \mathrm{~d}$ ) and $140^{\circ} \mathrm{W}$. Both are seasonal (Yu and McPhaden, 1999), with generally stronger transport at $140^{\circ} \mathrm{W}$ that declines in El Niño years. However, transports at $165^{\circ} \mathrm{E}$ and $140^{\circ} \mathrm{W}$ are congruent in May-August 1998. 20 This may reflect complete upstream PCC (given 1998 peak) with no further downstream aggregation. Tidal periodicities in Fig. $8 \mathrm{e}$ to j are discussed in Sect. 7.

What shapes the Pacific countercurrent system is not yet resolved. The Kessler et al. (2003) model does not reproduce observed eastward transport at $3^{\circ} \mathrm{N}$ to $6^{\circ} \mathrm{N}$ west of the date line, and places the NECC farther north in the western Pacific than 25 Johnson et al. (2002) observe. Also, the Brown and Fedorov (2010) model simulates a western EUC with up to 50\% less transport than Johnson et al. (2002) observe. These simulations share a countercurrent system that is generally less consolidated than is observed, even after adding nonlinearities to the Sverdrup relationship. In a momentum balance of the 1997-1998 event, Grodsky and Carton (2001) conclude
$6,905-961,2010$

\section{Global cooling by equatorially symmetric La Niña}

J. H. Duke

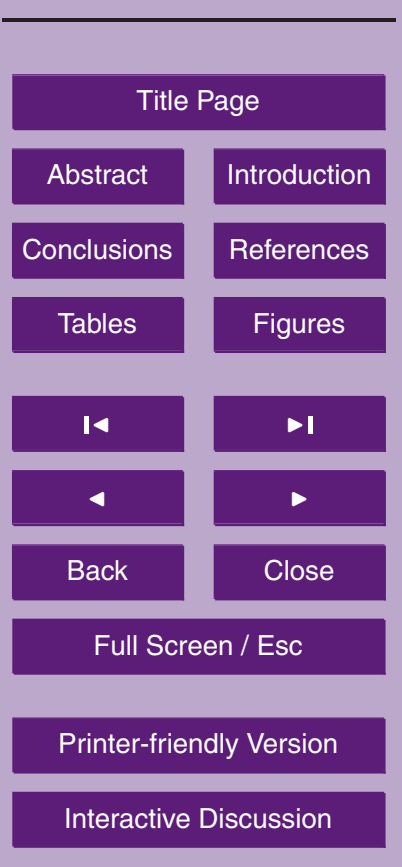


that local acceleration, zonal pressure gradient anomaly, and wind induced momentum flux were uncorrelated when the ESLN cold eye developed in May 1998. They attribute this to non-linear vertical advection and mixing processes, and Fig. $4 \mathrm{e}$ indicates ITR is present at that time and place. Near the equator, where Kessler et al. (2003) deduce 5 friction must occur, the stratifying effect of Coriolis that reduces diapycnal diffusivity with latitude (Gregg et al., 2003) would intensify stress in reactions to un-modeled ITR-forced thermocline heaving.

\section{PCC by ITCZ migration}

Sverdrup (1947) describes the axis of "the countercurrent" as "coinciding approximately with the location of the equatorial calm belt which is found further to the north in summer than in winter." So the mean wind pattern whose curl leads the NECC north (and weakens the SECC) is the same as defines the present northward bias of the ITCZ (Philander et al., 1996; Wang and Wang, 1999; Xie, 2005 review; Takahashi and Battisti, 2007). Orbital cycles that govern the ITCZ position may therefore also govern 15 PCC. This is proposed to be a parallel means of PCC forcing.

The manor of seasonal NECC migrations may explain the observed abruptness of both major glacial terminations and millennial timescale transitions (Taylor et al., 1993; Steffensen et al., 2008), which suggest that some threshold separates distinct equilibria. The NECC's seasonal migrations model such jumps. Figure $8 \mathrm{c}$ shows meridional shifts in eastward surface transport at $140^{\circ} \mathrm{W}$, where the NECC is stable in the north when southeast trade winds are strong, disappears as the ITCZ migrates south with weaker trade winds in March and April, and suddenly reappears on the equator in late boreal spring. Yu and McPhaden (1999) call this the "springtime SEC reversal", but it could also be described as "springtime PCC" because it coincides with NECC interruption. The absence of a slow NECC meander suggests that PCC is an attractor below some threshold in cross equator southeast trade wind strength. Wang and Wang (1999) describe "a delicate balance between counter effects of the antisymmetric
$6,905-961,2010$

\section{Global cooling by equatorially symmetric La Niña}

J. H. Duke

Title Page

Abstract Introduction Conclusions References

Tables Figures

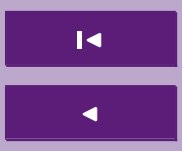
- I

Back

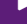

Close

Full Screen / Esc

Printer-friendly Version

Interactive Discussion

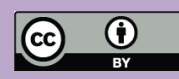


solar forcing and [ITCZ] self-maintenance". Presumably the stable northward bias due to basin shape (Philander et al., 1996) and mountain effect (Takahashi and Battisti, 2007) means that the ITCZ's southward excursions stop at the equator.

\section{ESLN by PCC}

5 ESLN is proposed to be the common mode of Pleistocene global cooling in all its frequencies, distinguished from other La Niña by its "cold eye" configuration. While the initial function of PCC is to trigger the eastward surge of warm surface water at EI Niño onset, its role in the later phase of the ENSO is to raise the EUC to the surface in the ESLN cold eye. Jones (1973) describes the process by which EUC shear energy converts to potential energy in the underlying pycnostad, or so-called "thermostad" or " $13^{\circ} \mathrm{C}$ water" (in the sense that the center of gravity of a mixed water column is higher than if stratified), yet Harrison and Weisberg (2008) call the pynostad "poorly understood". The bottom of the pycnostad is the level basin-wide $12^{\circ} \mathrm{C}$ isotherm at $300 \mathrm{~m}$ (see Fig. 3 of Johnson et al., 2002), so thickening it locally elevates the overlying ther15 mocline locally. By definition, PCC concentrates zonal shear at the equator to that end. Mixing that builds the thermostad is qualitatively unique because, once through the hard equatorial stratification (Gregg et al., 2003), Coriolis turns vertical, so eastward acceleration deflects water upwards.

Kessler et al. (2003) also demonstrate that mean zonal EUC shear is greatest near 20 $140^{\circ} \mathrm{W}$ to $110^{\circ} \mathrm{W}$. If shear magnifies ITR, this may explain why that is where the cold eye develops (Fig. 4e).

Figure 9 illustrates the prominent 1998 example of ESLN. Average surface current during July 1996 (a) exemplifies the textbook NECC position trending northward per Sverdrup (1947), July 1997 (b) shows the surge of the El Niño's geopotential release, and July 1998 (c) shows the eastward PCC surface jet near $140^{\circ} \mathrm{W}$, having emerged in May, with the NECC conspicuously absent (and in Fig. 8c). Recall that this is also when
$6,905-961,2010$

\section{Global cooling by equatorially symmetric La Niña \\ J. H. Duke}

\section{Title Page}

Abstract

Introduction

Conclusions

References

Tables

Figures

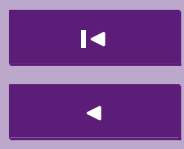

$\Delta$

Back

$\checkmark$

Close

Full Screen / Esc

Printer-friendly Version

Interactive Discussion

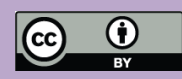


eastward subsurface transport at $165^{\circ} \mathrm{E}$ peaks (Fig. 8d). The SECC is present, aligned with the South Pacific convergence zone, which suggests a southward ITCZ shift as Vecchi (2006) observes (also in 1982-1983). Figure 9d is the average July 1998 chlorophyll anomaly (Chavez et al., 1999), showing an intense bloom co-located with 5 the eastward surface jet (Ryan et al., 2002). Figure 9e shows average July 1998 sea surface height anomaly, recognizable as the negative expression of the meridional seesaw mode of Alory and Delcroix (2002) (also in 1982-1983). This mode is defined by changes in geostrophic transport across $5^{\circ} \mathrm{N}$ that dominate buildup and depletion of the equatorial band. The band of positive sea surface anomaly (red and white) along $1010^{\circ} \mathrm{N}$ reflects the absence of the thermocline ridge that normally defines the NECC's northern boundary (Wyrtki and Kilonsky, 1984). The corresponding July 1998 sea surface temperature anomaly (f) indicates the cold eye configuration, and the resulting meridional winds $(\mathrm{g})$, indicate divergence in a winter monsoon cell. This cell divides both Walker and Hadley circulations, so the equatorial thermocline no longer shoals 15 monotonically eastward, but rather remains shallowest in the central Pacific where sea level is lowest (Fig. 9e). NOAA/PSD data (www.cdc.noaa.gov) shows an increase in outgoing longwave radiation at $0^{\circ}, 140^{\circ} \mathrm{W}$ in mid-1998, indicating subsidence.

Absence of the $10^{\circ} \mathrm{N}$ thermocline ridge may also enhance upwelling within the cold eye. Johnson and McPhaden (1999) calculate that the usual potential vorticity barrier at this ridge limits the northern source of pynocline water to the sub-tropical cell to $1 / 3$ of the southern source. Meyers and Donguy (1984) also observe disappearance of the ridge in the second year of the 1982-1983 event, in which the ITCZ pattern was similar to the 1997-1998 event (Vecchi, 2006). Interestingly, if a northern pynocline barrier favors upwelling south of the equator, which would contribute to northern ITCZ bias (Xie and Philander, 1994), then it enhances ITCZ bimodality.

Because PCC triggers ENSO, ESLN is preceded by EI Niño if the volume of warm water in the western Pacific is sufficient. Therefore the global cooling potential of ESLN is not in a suppression of El Niño per se, but rather in a frequency of PCC forcing that is high enough to limit warm water recharge, as in 1999 to 2001 . In that case a permanent
$6,905-961,2010$

\section{Global cooling by equatorially symmetric La Niña}

J. H. Duke

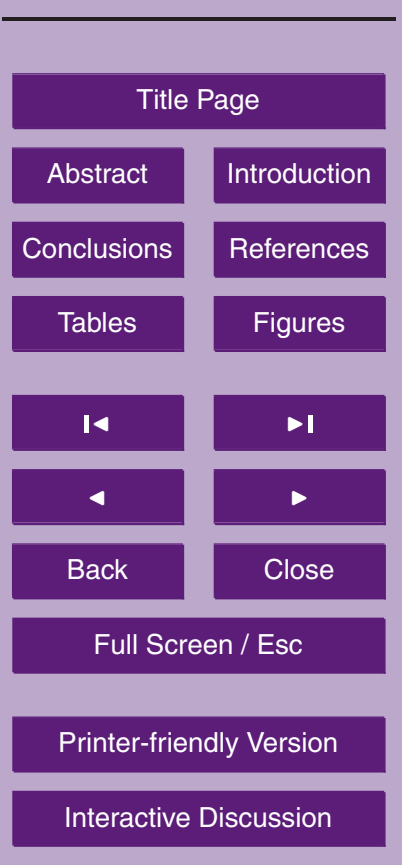


ESLN in the sense of a Broecker (2003) "flywheel" is not a necessary condition of global cooling.

\section{Global cooling by ESLN}

Four possible global cooling effects of ESLN are described. All would be enhanced 5 if thermocline shoaling progressed beyond the 1998 case to where the pycnostad breaches the surface. In that circumstance upwelling would accelerate dramatically.

First, division of the Hadley cell by the cold eye winter monsoon cell reduces production of water vapor, a potent greenhouse gas. This is consistent with Broecker (1997), Cane (1998), Cane and Clement (1999), and Seager et al. (2000), and meets the at10 mospheric albedo and glacial hemispheric synchronicity tests of Broecker and Denton (1989). Also, Oort and Yienger (1996) found an inverse relationship between Hadley circulation strength and La Niña events.

Second, deflated Hadley circulation abruptly constricts the width of the entire tropical belt, which pulls dry subtropical subsidence zones closer to the equator, the op15 posite of what Seidel (2008) observes in recent decades. This in turn draws southern circumpolar westerlies equatorward, which is a potentially instantaneous effect, for Hanna (2001) records a 2.2 standard deviation increase in Antarctic sea ice in September 1998 as circumpolar westerlies shifted north, which he attributed to ENSO. In the Steffensen at al. (2008) study, 1 to 3 year shifts in deuterium excess in North 20 Greenland ice cores indicate warmer marine moisture sources during global coolings, consistent with equatorward displacement of the polar front that envelops polar moisture sources. Toggweiler et al. (2006) link equatorward migration of Antarctic westerlies to atmospheric $\mathrm{CO}_{2}$ drawdown at glacial onset. The same displacement also restricts Augulas leakage of high salinity thermocline water at the Cape of Good Hope that 25 supplies North Atlantic deep water production (Peeters et al., 2004). Completing a six ocean circle of causation, Timmermann et al. (2007b) describe a cross-Panama teleconnection through which weakened Atlantic overturning then strengthens north-east
$6,905-961,2010$

\section{Global cooling by equatorially symmetric La Niña \\ J. H. Duke}

\section{Title Page}

Abstract Introduction

Conclusions References

Tables Figures

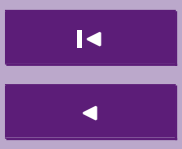
DI

Back

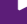

Close

Full Screen / Esc

Printer-friendly Version

Interactive Discussion

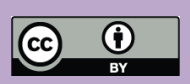


trade winds in the eastern Pacific, which would shift the eastern Pacific ITCZ south and further support ESLN.

A possible third global ESLN effect is on $\mathrm{CO}_{2}$ flux from the central and eastern equatorial Pacific, which is presently the ocean's largest $\mathrm{CO}_{2}$ source area (Takahashi et al., 5 2002). Because $\mathrm{CO}_{2}$ efflux during usual La Niña increases due to a combination of stronger wind and more upwelled $\mathrm{CO}_{2}$ rich thermocline water, an ESLN role in glacial $\mathrm{CO}_{2}$ drawdown would depend upon very high export production. The record-setting 1998 plankton bloom shown in Fig. 9d (Chaves et al., 1999) provides a possible template for that role, given evidence of peak carbonate sedimentation rates at glacial 10 onset along $140^{\circ} \mathrm{W}$ (Murray et al., 2000a, b). Lyle et al. (1992), Pedersen (1983), Paytan et al. (1996), and Beaufort et al. (2001) also observe increased glacial sediment accumulation rates in the equatorial Pacific. Kienast et al. (2006) also observe increased surface ocean productivity in the eastern equatorial Pacific during millennial cold phases (Heinrich event 1 and the Younger Dryas). Because the eastward jet 15 (Fig. 9c) is EUC water containing iron (Ryan et al., 2002; Wells et al., 1999), the 1998 ESLN may be regarded as Earth's largest natural iron fertilization experiment (Coale et al., 1996).

Last, related to mid Pacific stadial and glacial plankton blooms, the Charlson et al. (1987) cloud seeding hypothesis by biogenic dimethyl sulphide (DMS) could increase status clouds flanking the cold eye. Turner et al. (1996) observe a local 3.5x increase in DMS concentration during an equatorial Pacific iron enrichment experiment.

The proposed global cooling roll of ESLN may resolve four apparent contradictions in proxy records. First, Hadley cell constriction by ESLN may explain why short stadial events are not hemispherically synchronous, while long ice ages are. As mentioned above regarding the Steffensen at al. (2008) study, a cold phase ESLN that pulls the southern polar front northward exposes a greater fraction of the Antarctic envelope to open ocean, creating a more maritime climate, and vice versa. This centennial Antarctic response could result from the same ESLN driven polar front migration that has the opposite effect in longer timescales. Barker et al. (2009) infer a southward Antarctic
6, 905-961, 2010

\section{Global cooling by equatorially symmetric La Niña}

J. H. Duke

\section{Title Page}

Abstract

Introduction

Conclusions

Tables

References

Figures

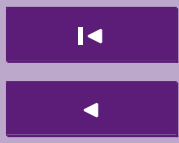

$\rightarrow 1$

Back

$\checkmark$

Close

Full Screen / Esc

Printer-friendly Version

Interactive Discussion

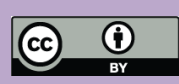


Circumpolar Current shift during stadials from decreased polar fauna at $41.1^{\circ} \mathrm{S}, 7.8^{\circ} \mathrm{E}$, but that could also indicate the reverse due to an Augulas current intrusion (Peeters et al., 2004), or the Pacific sector response may be different, and dominant, by proximity to the cold eye (Hanna, 2001).

5 Second, the separation of the ESLN cold eye from the South American coast may explain conflicting SST proxies in the far eastern Pacific. Whereas Cane (1998) associates La Niña with ice ages, Koutavas at al. (2002) conclude that higher stadial SST near the Galapagos indicates EI Niño, as Ortiz at al. (2004) also observe at a site near the southern tip of the Baja Peninsula. However, the core locations used in 10 these studies are within the Fig. 9f warm anomalies in the far eastern Pacific during the 1998 ESLN. The distinction between the cold eye and the cold tongue reflects midPacific shear concentration noted above (Kessler et al., 2003). But the Trend-Staid and Prell (2002) SST reconstruction shows usual La Niña conditions (cooler in the east) prior to glacial termination.

15 Third, the ESLN - La Niña distinction may also explain high stadial sea surface salinity in the western warm pool region, which Stott et al. (2002) attribute to the modern El Niño pattern in which deep convection migrates eastward. The core location of the Stott et al. (2002) study, at $6.3^{\circ} \mathrm{N}, 125.8^{\circ} \mathrm{E}$, is central to the East Asian Monsoon system whose winter dry season mode strengthened during glacial periods, with prominent precessional forcing (Beaufort et al., 2003). Clemens et al. (2003) provide East Asian Monsoon climatologies (their Fig. 1) in which the winter dry season winds are north-easterly at the Stott et al. (2002) core location. This is what is observed in July 1998 (www.esrl.noaa.gov), so southward ITCZ migrations associated with ESLN (either precessional or imposed by ITR) could have the same result. Additionally, if glacial ESLN were persistent, westward SEC surface transport from the ESLN cold eye would reflect increased upwelling of saline thermocline water and increased evaporation under ESLN subsidence.

Last, a weak link in the ESLN hypothesis is how to explain stadial Heinrich event iceberg discharge (Heming, 2004). All else being equal, an ESLN forced cold and dry
6, 905-961, 2010

\section{Global cooling by equatorially symmetric La Niña}

J. H. Duke
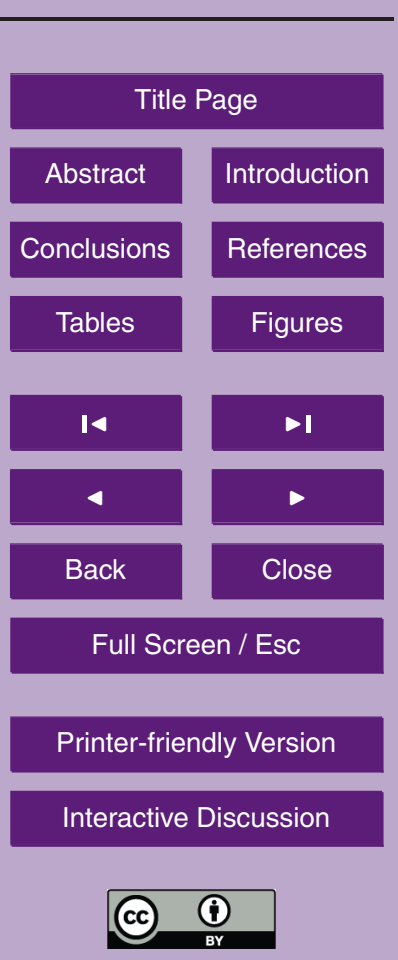
Arctic (Taylor et al., 1993; Steffensen et al., 2008) would inhibit glacier movement. But Seager et al. (2010) link La Niña to northward displacement of North Pacific storm tracks, and such air masses crossing the flat Northwest Territories, rather than turning south (Seager et al., 2002), could link the Gulf of Alaska to Hudson Bay. Precipita5 tion concentrated by altitude effect on the highest ice sheets would increases basal pressure where Heinrich events require it.

Global cold phases correspond with southward ITCZ displacements in both millennaial and precessional timescales (Haug et al., 2001; Koutavas and Lynch-Stieglitz, 2005; Wang et al., 2004). In the former, the ESLN cold eye imposes the ITCZ shift, 10 whereas the above precession contol reverses that chain of causation.

\section{Short periodicities}

Short cycles in PCC forcing by ITR work through interaction with both the seasonal cycle and the semiannual cycle of equinoctial tide maxima. Equinoctial tides are strong on the equator because the sun's tidal vector passes through the same water twice a 15 day, and the moon's within $\pm 5^{\circ}$ declination. Similarly, eclipses increase tidal potential when the sun and moon's tide vectors pass through each other. The eclipse cycle is a progression towards and away from that "centrality", which repeats in fortnightly groups of 2 or 3 eclipses every 5 or 6 months. Centrality of individual eclipses is ranked by a gamma value representing the minimum passing distance of the moon's center to the axis of the sun's earth shadow cone, expressed in earth radii, positive or negative for north or south of the ecliptic. Eclipses also perturb adjacent perigee-sysygy intervals as described below.

Intermediate length low latitude tidal periodicities stem from the 18 year plus 10 day Saros cycle of repeating eclipses known in Baylonian times (Steves, 1998), which is distinct from the 18.6 year nodical cycle in high latitude diurnal tides. Individual Saros series may exceed 1400 years, and the gamma values of their eclipses converge to
$6,905-961,2010$

\section{Global cooling by equatorially symmetric La Niña}

J. H. Duke

Title Page

Abstract Introduction

Conclusions

References

Tables

Figures

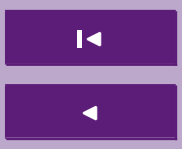

$\Delta$

Back

$\triangleright$

Close

Full Screen / Esc

Printer-friendly Version

Interactive Discussion

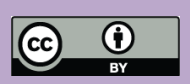


zero (most central) at their midpoints. The gamma value of the least central eclipses is approximately \pm 1.6 at Saros endpoints (http://eclipse.gsfc.nasa.gov/eclipse.html). Lunar and solar Saros series are numbered separately. As it happens, the midpoints of successive Saros series are separated by the 29 year less 20 day INEX interval 5 of van den Burgh (1955). At any given time, approximately 58 overlapping solar and lunar Saros series progress through the observed 5 to 6 month eclipse cycle, but their collective degree of centrality varies over time, as described below.

For background, the Saros is equal to 223 synodic months (mean $\mathrm{S}=29.530589$ days new moon to new moon or full moon to full moon) and 242 Draconic months (mean $10 \mathrm{D}=27.21222$ days node to node when the moon crosses the ecliptic). The S-D beat period, $1 /((1 / D)-(1 / S))$, is the 346 day eclipse year $(11.73766 \mathrm{~S}=12.73766 \mathrm{D}), 19$ of which approach the integer Saros at $223 \mathrm{~S} \approx 242 \mathrm{D}$. The INEX equals $358 \mathrm{~S}$. Each eclipse year contains two eclipse cycles (when each of the moon's nodes faces the sun), irrespective of perigee. 242 being even, the half Saros is $111.5 \mathrm{~S}$, which alternates solar and 15 lunar eclipses in 19 eclipse cycles. Due planetary resonance (Steves, 1998), the Saros is also 239 anomalistic months (mean $A=27.554551$ days perigee to perigee). The $\mathrm{S}-\mathrm{A}$ beat period $(13.94434 \mathrm{~S}=14.94434 \mathrm{~A})$ is 411.78 days, 16 of which approach the integer Saros at $223 \mathrm{~S} \approx 239 \mathrm{~A}$. The S-A beat also approaches the 413.37 day evection period at $14 \mathrm{~S} \approx 15 \mathrm{~A}$.

Because there are two lunations per synodic month, at the ends and near the middle of each S-A beat period there is a mutual 3-body attraction in space that draws the moon closer to earth at proxigee, yielding 16 proxigees per half Saros. But as 15 is odd, the perigee cycle cannot also divide in half, so proxigee repeats after either $7 \mathrm{~A}$ or $8 \mathrm{~A}$, yielding a mean 207 day period. The gravitational attraction of this asymmetric sysygy then results in a mutual perturbation of contracting $S$ and expanding $A$, in which the advance of lunar perigee in longitude actually reverses direction (Wood, 1986). The tidal significance of this perturbation is that proxigee occurs within 4 month long spans of reduced perigee-sysygy intervals. December 1996 to April 1997 and January to May 1998 are such intervals.
$6,905-961,2010$

\section{Global cooling by equatorially symmetric La Niña}

J. H. Duke

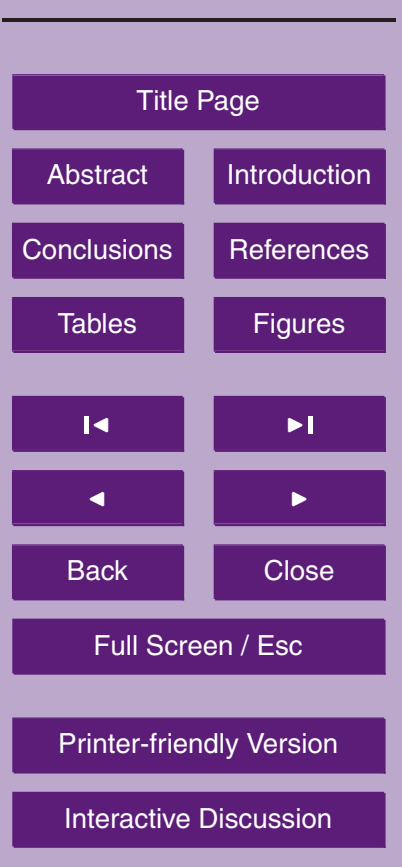


An attribute of low gamma eclipses (hereafter LGE), with absolute value of gamma below approximately 0.25 , is that the lunations immediately before and after are also eclipses, forming a triple as centered on 16 July 2000 in Fig. 7. Such triples are either lunar/solar/lunar (L/S/L) or solar/lunar/solar (S/L/S) type. A second LGE attribute is that 5 if a member of such a triple occurs within $24 \mathrm{~h}$ of perigee, it is proxigee, and therefore centers a reduced perigee-sysygy interval.

Referring again to Fig. 8 for 1993 to 2011, lunar distance (e) indicates the proxigee cycle. Next, a western Pacific tidal energy measure is provided by the daily sum of vertical tidal displacements at the Marshall Islands (f). These sums reflect both the 10 equinoctial extremes (Figs. $1 \mathrm{~b}$ vs. $2 \mathrm{~b}$ ) and the effect of reduced diurnal inequality at the equinox (Wood, 1986), but ENSO related changes in sea level (Wyrtki, 1985) cancel. There are generally four differences per day between higher high water $(\mathrm{HHL})$, low water (LW), high water (HW), and lower low water (LLW); in the rare cases of 3 or 5 , the daily sum is multiplied by $4 / 3$ or $4 / 5$ respectively, which does not alter the form

of the curve. The equinoctial concentration of low latitude tidal energy is clear, and the maximum daily value between 1993 and 2011 is at proxigee on 28 March 1998. Next, the progression of eclipse cycles $(\mathrm{g})$ scales absolute value of gamma. Note 19 eclipse cycles and 16 proxigees in the 1997 to 2009 half Saros interval, according to S-D and S-A beat periods. Lastly, the amplitude of the S-A perturbation is indicated by successive deviations from mean anomalistic (h) and synodic months new moon to new moon (i) and full moon to full moon (j) (not scaled in time). Anomalistic months vary in the length by up to 3.9 days, while the complimentary synodic month variation is 0.5 days. Note the coincidence of proxigee (e), long anomalistic months (h) and new (i) or full (j) synodic months, which result in reduced perigee-syzygy intervals.

Given the above tidal periodicities, four overlapping ITR-PCC forcing cycles are proposed. LGE are extremes in S-D commensurability that incrementally increase tidal potential. It may be that the physical significance of LGE is in their greater perturbation of perigee sysygy intervals.

First, it can be seen in Fig. $8 f$ that tidal energy increases in an approximate 4.5 year
$6,905-961,2010$

\section{Global cooling by equatorially symmetric La Niña}

J. H. Duke

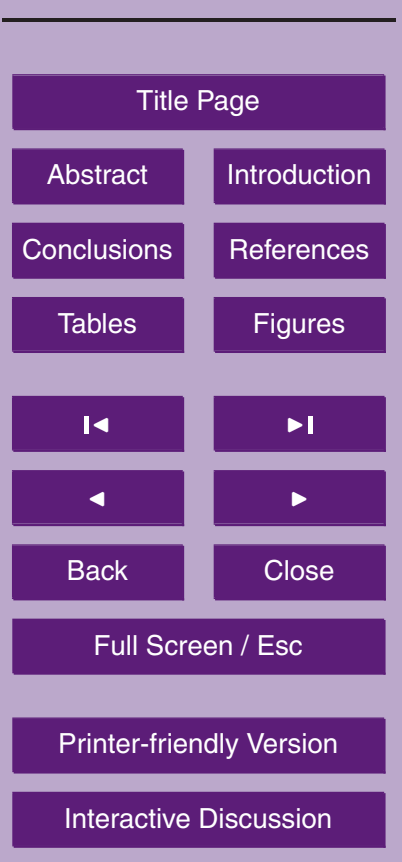


period when proxigee is commensurate with the March equinox, in 1993-1994, 1998, 2002, and 2006-2007, which are ENSO years. Projected tidal energy in 2010 and 2011 is also strong. This is the cycle noted above that correlates with observed WWB activity in Fig. 3d. Alignment with the September equinox is less significant given ENSO 5 seasonality.

Second, as eclipse cycles $(\mathrm{g})$ are commensurate with the annual cycle in the nine year half Saros, March eclipses repeat in 1997 and 2006. Note in Fig. 5d that the seasonal zonal current cycle (Yu and McPhaden, 1999) is amplified when in phase with the eclipse cycle.

10 The third cycle, which extends ITR-PCC forcing into the millennial domain, is in the frequency and seasonality of LGE. It also involves the half Saros, but only over the decades spanning their series' midpoints. Figure 10a extends the Fig. $8 \mathrm{~g}$ plot of absolute value of $\gamma<0.75$ over the 800 year interval 1600 to 2400, in which eclipses occurring within 30 days of 21 March (as in 1997 and 2006) are indicated in red. 15 This reveals a 586 year cycle in which LGE are most frequent, and also equinoctial, near 1760 and 2340. This distribution is consistent with the Gergis and Fowler (2009) reconstruction, which finds a period of high La Niña frequency between the 1720's and early 20th century. Their peak La Niña decade is the 1750's. The physical basis for the 586 year cycle is illustrated in a corresponding day-year plot of LGE (b). Red diamonds and blue circles respectively represent L/S/L and S/L/S types, so positive sloping series indicate the half Saros advance of 5 days per 9 years. The INEX slope (green) regresses 20 days per 29 years, drawn through the 16 July 2000 LGE. This figure therefore represents the Saros-Inex Panorama of van den Bergh (1955) plotted in time, but only showing the most central eclipses (LGE). Red (blue) lines linking interpolated zero gamma points of solar (lunar) Saros series describe a wave form of that deviates from the INEX in a way that yields the LGE distribution of Fig. 10a. Placement of yellow squares corresponds to which eclipse of each triple (L/S/L or S/L/S type) peaks within $24 \mathrm{~h}$ of proxigee. In the present epoch proxigee falls predominantly on solar LGE.
6, 905-961, 2010

\section{Global cooling by equatorially symmetric La Niña}

J. H. Duke

\section{Title Page}

Abstract

Introduction

Conclusions

Tables

References

Figures

14

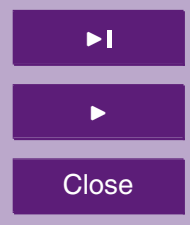

Back

Close

Full Screen / Esc

Printer-friendly Version

Interactive Discussion

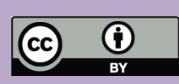


Van den Bergh (1955) provides an astronomical measure of the LGE distribution in the 586 year Tetradia cycle in repeating lunar tetrads (four successive total lunar eclipses), which Meeus (2004) shows are anti-correlated with "duos" of one type, which in turn bracket LGE that form S/L/S or L/S/L triples.

The detail view of Fig. 11 contrasts the gamma distribution (a) of Fig. 10a with the 1871-2006 Niño 3.4 record (b) of Trenberth and Stepaniak (2001) extended to 2009. A 48 month running sum of months with negative Niño 3.4 anomaly (c) shows a declining trend that mirrors the increasing gamma trend in (a). There is a suggestion that extended cold periods follow LG events after 1890, 1908, 1957, 1973, and 1999. No10 tably, the three highest Niño 3.4 anomalies prior to 1997 (December, 1877, 1888, and November 1982) each follow extreme LGE by 4 to 5 months, a lag that is consistent with the Hendon et al. (2007) analysis linking spring MJO to maximum fall El Niño amplitude. The centered Saros series of the present epoch (Lunar \#129 and Solar \#136) have LGE on 30 June 1973 ( $\gamma=-0.079), 6$ July $1982(-0.058), 11$ July $1991(0.004)$, 1516 July 2000 (0.030), and 22 July 2009 (0.070). All are EI Niño years except 2000 when warm water volume was depleted. The 29 year INEX period that separates successive Saros series causes a phase shift of 2 years between overlapping series $(29-3 \times 9)$. These shifts complicate long interval spectral analysis of the ENSO, and would tend to yield spectral power in pairs that add to 9, especially prior to 1960 when more LGE series overlap. This could explain the reduction in ENSO frequency in the 1970's.

The zero gamma wave form of Fig. 10b reflects a variation in the rate of change of gamma. Note that LGE series whose zero gamma points are near the present 5 July aphelion have the fewest members, and that zero gamma lines shift discontinuously across the present 4 January perihelion. Figure 12 plots gamma against time for the complete lunar Saros series numbered in Fig. 10b. In the "lifetime" of individual Saros series, the 10 (or 11) day advance per 18 years laps the calendar two or three times. What is observed is that the rate of change of gamma accelerates passing aphelion and slows at perihelion, so \#138 crosses zero later than \#139, though it begins earlier. This results from "stern chase" variation in the length of the synodic month, a term of
$6,905-961,2010$

\section{Global cooling by equatorially symmetric La Niña \\ J. H. Duke}
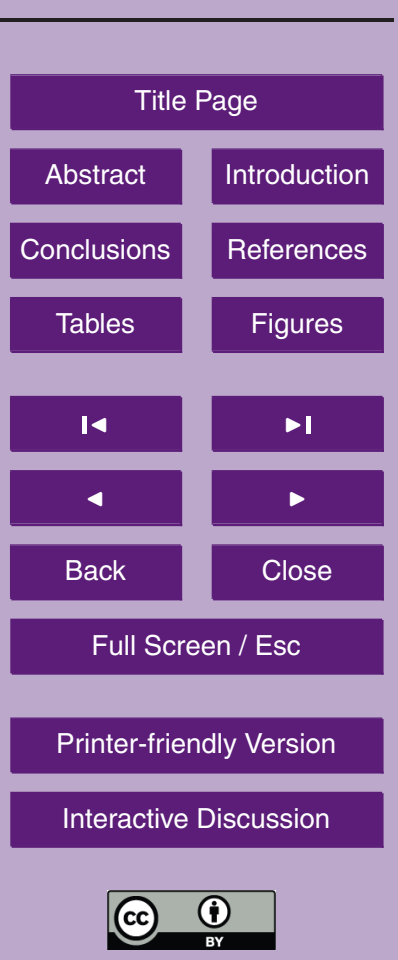
nineteenth century celestial navigation referring to time the moon requires to catchup with Earth at sysygy. Between 1800 and 2050, synodic months ending in July (near aphelion) are an average of $4.07 \mathrm{~h}$ shorter than those ending in January (near perihelion) (MICA). This is significant relative to the $12 \mathrm{~h}$ perturbation in $\mathrm{S}$ in Fig. $8 \mathrm{i}$ 5 and $\mathrm{j}$. As Earth slows at aphelion, the stern chase becomes shorter, which shortens $S$, so its progression to commensurability with $D$ accelerates with respect to the INEX. Conversely, progression to commensurability slows approaching perihelion, until the zero gamma point "jumps" across perihelion, yielding the observed zero gamma wave form.

10 Figure 13 extends the Fig. 10b day-year LGE plot over 5 millennia, and also indicates the precessional advance of aphelion. Only perigees that are symmetrical with LGE triples (centered or bracketing) are shown. The relationship between successive wave forms reflects the fact that 10 Inex $=16$ Saros $+12 \mathrm{~S}$, as all eclipses have neighbors $12 \mathrm{~S}$ ahead and $12 \mathrm{~S}$ behind whose Saros series numbers differ by 10 Inex steps. So 15 the wave to wave transition is a $12 \mathrm{~S}$ phase shift. As contrast in the 586 year cycle is due to stern chase deviation from the INEX, its contrast would increase with Earth eccentricity near the present configuration.

The relation of perigee to LGE is governed by the anomalistic month's commensurability with the $358 \mathrm{~S}$ INEX interval. $358 \mathrm{~S}$ is incommensurate with $\mathrm{A}$, leaving a remainder of 0.673 . Therefore the first close fit is at 3 Inex $=1074 \mathrm{~S}=1151.02 \mathrm{~A}=86.83$ years, and proxigee is therefore concentrated at every third Saros series in Figs. 10b and 13. This period is reflected in the spectral analysis of Treloar (2002), who correlates tidal maxima with high (cold phase) SOI in 86.795, 20.295, and 18.02 year "mid-latitude" cycles. The Saros is 18.03 years. Higher S-A commensurabilities are at $15,283 S \approx 16,279 A=1,237$ years, $20,805 S \approx 22,297 A=1,682$ years, and $22,548 S \approx 24,165 A=1,823$ years, which relates to the Keeling and Whorf $(1997,2000)$ 1,800 year period. Of these, 1,237 and 1,823 are near $2 \times$ and $3 \times$ multiples of 586 . On this basis, the forth proposed tidal forcing cycle incorporates proxigee, at $2 \times$ or $3 x$ multiples of the 586 year LGE cycle, equal to 1,172 and 1,758 years. Bond et al. (1999)
6, 905-961, 2010

\section{Global cooling by equatorially symmetric La Niña \\ J. H. Duke}

\section{Title Page}

Abstract

Introduction

Conclusions

Tables

References

Figures

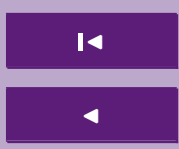

$\Delta$

Back

Close

Full Screen / Esc

Printer-friendly Version

Interactive Discussion

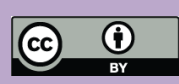


observe cold phase periods in a range between 1,328 and 1,795 years that average $1476 \pm 585$ years, corresponding to the 1,470 year Greenland Ice Sheet Project 2 spectral peak (Grootes and Stuvier, 1997). However, the nearby Greenland Ice Core Project record shows separate peaks at 1,163 and 1,613 years (Hinnov et al., 2002), and a 5 Sulu cave record yields separate peaks at 1,190 and 1,667 years (Clemens, 2005).

Figure 14 compares 50 year sums of all eclipses (a), LGE with absolute value of $\gamma<0.1$ (b), and LGE with absolute value of $\gamma<0.25$ differentiated by season (c), \pm 75 days from 21 March (blue), 5 July (green), and 21 September (red). Contrast in the number of all eclipses (a) is due to the extra one in each LGE triple, causing an in- crease in aggregate tidal forcing. The seasonal effect reduces contrast in the 586 year LGE cycle when the zero gamma progression is near aphelion (green). In the interval shown, contrast at the September equinox is decreasing (red), while contrast at the March equinox is increasing (blue). Minimum March LGE frequency is between 2000 and 2049. Vertical bars in Fig. 14a indicate a $2 \times 586$ year period coherence with the Lit15 tle Ice Age and Bond cycles \#1, \#2, and \#3 (glass) (Bond et al., 1999). An intermediate LGE peak corresponds with the 1150 drought in the Americas (Cook et al., 2004). The Steffensen et al. (2008) study shows 400-650 year centennial cycles within millennial cycles. To illustrate the signature interference pattern of the Saros, Figure 12d plots plus and minus gamma for the succession (not scaled in time) of all eclipses within 2075 days of 21 March.

\section{Long periodicity}

Possible PCC-ESLN forcing is by both ITR and ITCZ migration in the known orbital periods of precession (19-23 kyr), obliquity (41 kyr), and eccentricity (100 and $400 \mathrm{kyr}$ ). For the past 3 million years, Fig. 15 provides mid-month (Berger, 1978) March insolaLaskar et al., 2004, solution), the LRO4 $\delta^{18} \mathrm{O}$ ice proxy stack (b) (Lisiecki and Raymo, 2005), and obliquity angle (c) (Berger, 1991). Half precession cycles between March

$6,905-961,2010$

\section{Global cooling by equatorially symmetric La Niña}

J. H. Duke
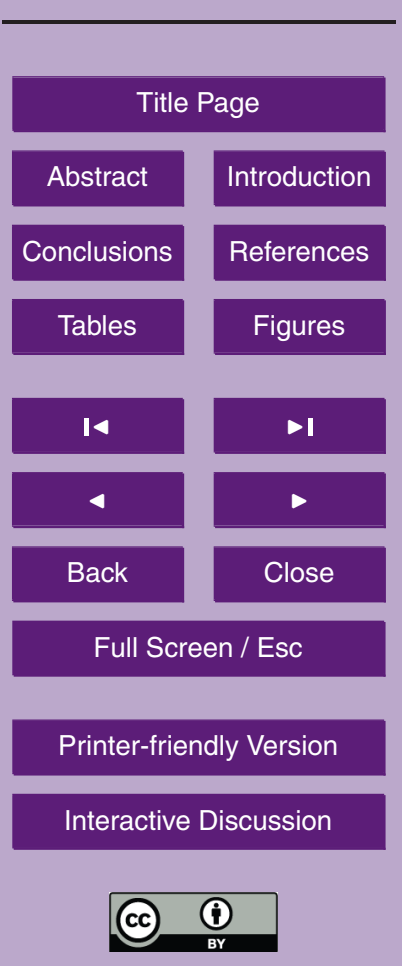
and September perihelion are highlighted in red, and intervals of obliquity $>23.5^{\circ}$ are highlighted in green. Note that there are both anomalously long and short half precession intervals when eccentricity (precession amplitude) is low (Berger, 2003), and the duration of the high obliquity windows decreases with obliquity amplitude. Uncertainty 5 in the LR04 stack is 4 kyr since 1 million years ago (Ma), and 6 kyr from 3 to $1 \mathrm{Ma}$, with orbital tuning to obliquity (Lisiecki and Raymo, 2005).

In the precession cycle, as Berger (1978) observes in the most recent instance, intervals of fast melt exceeding $0.50 \% \circ \mathrm{dO}^{18}$ begin near March perihelion and end near September perihelion in 17 of 17 cases since $1 \mathrm{Ma}$, in 17 of 20 cases between 101 and $2 \mathrm{Ma}$ (exceptions are MIS 34, 36, and 42), and with weaker correspondence earlier. These selected darker red intervals in Fig. 15 are common to both $40 \mathrm{kyr}$ and $100 \mathrm{kyr}$ glaciations, which explains the apparent increase in ice age skewness with amplitude (Broecker and van Donk, 1970; Lisiecki and Raymo, 2007). Note that June perihelion, which is often linked to glacial termination (see Berger and Loutre, 2004), 15 is exactly in the middle of the above red intervals. Therefore if an ice response lag is assumed, the identical correlation in time can support a very different narrative of physical causation. Here the proposed physical basis for glacial termination at March perihelion is an abrupt northward migration of the ITCZ, which turns PCC and ESLN off. Following Clement et al. (1999, 2000, 2001) and Kukla and Gavin (2004, 2005), though equinoctial insolation is equatorially symmetric, the annual cross equator trade wind cycle is not. The equatorial Pacific adopts the seasonal cycle of the non-ITCZ southern hemisphere (Wang and Wang, 1999), which is warm in March and cold in September. Therefore March perihelion/September aphelion strengthens the annual cycle, which strengthens southeast trade winds in the eastern Pacific that displace the seasonal insolation contrast on the equator is greatest at the equinoxes (Kukla et al., 2002; Kukla and Gavin, 2004). Also, the noon sun is directly overhead in the ITCZ at $8^{\circ} \mathrm{N}$ in early April (not June) which may contribute to abrupt vernal ITCZ switching.

$6,905-961,2010$

\section{Global cooling by equatorially symmetric La Niña}

J. H. Duke
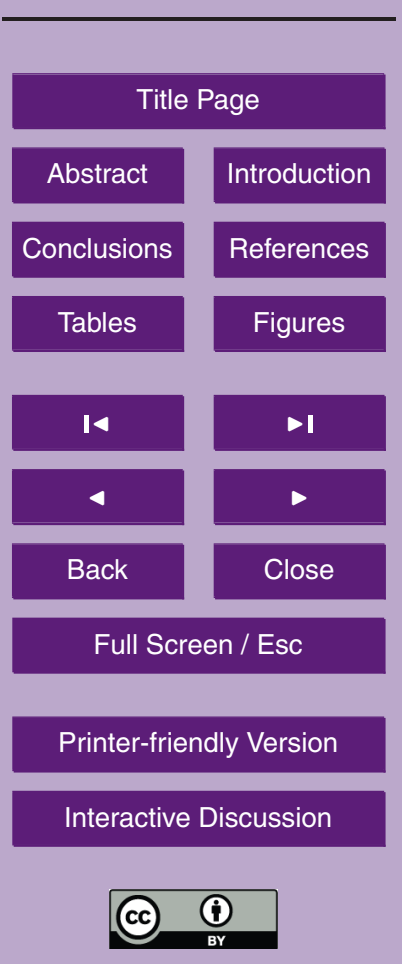
A consequence of the half precession fast melt interval, given the apparent fact that ice sheets accumulate slower in the other half, is that precessional glacial forcing can only manifest in an overtone, the first of which $(2 \times 19$ or $2 \times 23 \mathrm{Kyr})$ is spectrally close to obliquity. Exception to this rule would result in stepwise cycles leading to no ice.

$5 \quad$ The Timmermann et al. (2007a) modeling study concludes that the eastern Pacific annual cycle is anti-correlated with ENSO activity, consistent with a suppression of PCC-ESLN forcing within the above red intervals. But within LR04 uncertainty, the dynamic attributed to March perihelion at 111 thousand years ago (ka) may actually be greater at February perihelion at $113 \mathrm{ka}$, when Timmermann et al. (2007a) observe 10 an inflection in negative meridional $10 \mathrm{~m}$ wind anomaly (ITCZ switch), and Kukla and Gavin (2004) note both a minimum sea level stand and a minimum La Niña frequency in the Clement et al. (1999) experiment. This dynamic is corroborated on decadal timescales by the Chiang et al. (2008) and Fang et al. (2008) modeling studies, that link lower ENSO activity to higher northward interhemispheric temperature gradient (which 15 steepens as the annual cycle strengthens). The proposition here that warm periods have low ENSO activity of both types differs from the Clement et al. (1999) experiment which defines warm phases as high El Niño frequency. Their model (Zebiac-Cane) restricts ITCZ migration, so does not address the dynamic proposed here. Raymo and Nisancioglu (2003) and Kukla and Gavin (2005) also link global cooling to the crossequator temperature gradient, but towards bulk poleward heat and moisture transport rather than an ITCZ switch.

With respect to obliquity, Huybers and Wunsch (2005) and Huybers (2007) establish that high obliquity is also a necessary condition of glacial termination, based on statistical analysis of a successful three parameter model that adopts the $10 \mathrm{kry}$ ice volume reset interval of Marshall and Clark (2002). Huybers (2006) attributes this forcing to extended duration of northern high latitude warming. But the Marshall and Clark (2002) reset intervals are also the above half precessional intervals, so the interpretation here is that interruption of the default late Quaternary glacial state requires both March perihelion and rising obliquity $>23.5^{\circ}$, with exceptions at MIS 28 and 32
$6,905-961,2010$

\section{Global cooling by equatorially symmetric La Niña}

J. H. Duke
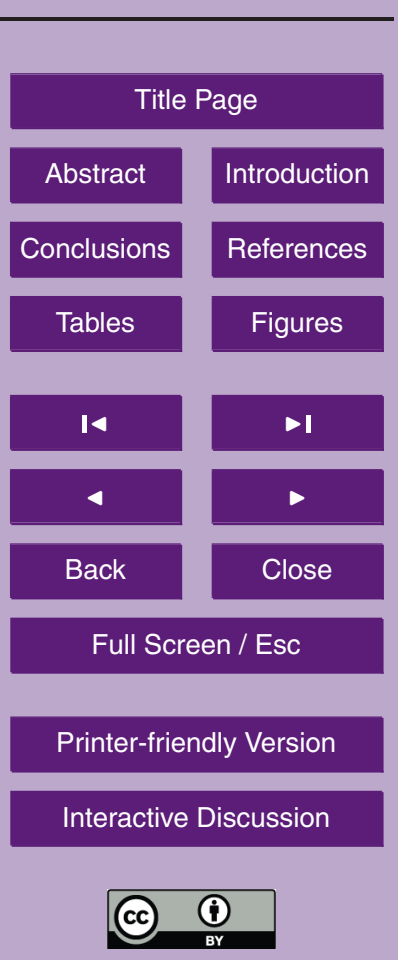
and some mid-glacial steps, for that is when the meridional gradient steepens fastest (high obliquity causing both low latitude cooling and high latitude warming). This reflects the Berger and Loutre (2004) "high-low-high" 1:2 dynamic in obliquity/precession conjunctions. Huybers (2007) shows that the late Pleistocene transition to longer cy5 cles is due to skipped obliquity cycles, but what determines which ones are skipped is not established (Liu et al., 2008) or considered chaotic (Huybers, 2009). But note in Fig. 15 that skipped obliquity cycles are the ones with the poorest alignment with March perihelion (at 50, 100,175, 380, 460, and $660 \mathrm{ka}$ ). Ruddiman (2006) observes variation in the ratio of obliquity and precession periods. It is predominantly $1: 2$ prior to $0.6 \mathrm{Ma}$ 10 when "high-low-high" 40 kyr cycles dominate, but is 3:5 between MIS 2 and 6, 2:5 between MIS 10 and 12, and 3:5 between MIS 12 and 14. The mid-Pleistocene transition may therefore reflect a change in the phase relation between quantized precession (Raymo, 1997) and quantized obliquity (Huybers, 2007). The period of precession is not constant (Berger et al., 2003).

15 Obliquity $>23.5^{\circ}$ also appears to play an important role in extending warm periods after September perihelion, when the slope of the LR04 record sometimes levels off (as at present and MIS 7, 13, 17, 37 and 47). This is consistent with the Huybers (2006) extended northern warming hypothesis. Taken together, a proposed combined precession-obliquity dynamic is: (1) termination begins near conjunctions of March perihelion and rising $23.5^{\circ}$ obliquity, (2) fast melt ends 10 kry later, (3) if obliquity $>23.5^{\circ}$ extend interglacial, (4) glaciation begins after September perihelion and before March perihelion when obliquity $<23.5^{\circ}$. In the MIS 11 case obliquity $>23^{\circ} 5$ continued after March perihelion.

Proposed PCC forcing by precession and obliquity paced ITCZ migration may be complimented by corresponding tidal forcing. The prominence of equinoctial tides in the low latitude annual cycle (Fig. 8f) indicates strong declination dependence, so higher obliquity would weaken mean ITR-PCC forcing, and compliment the Huybers (2006) insolation control. Possible tidal precession effects involve changing seasonality in 586 year cycle (Fig. 14c). The analysis of Schaffer and Cervany (1998)
$6,905-961,2010$

\section{Global cooling by equatorially symmetric La Niña}

J. H. Duke
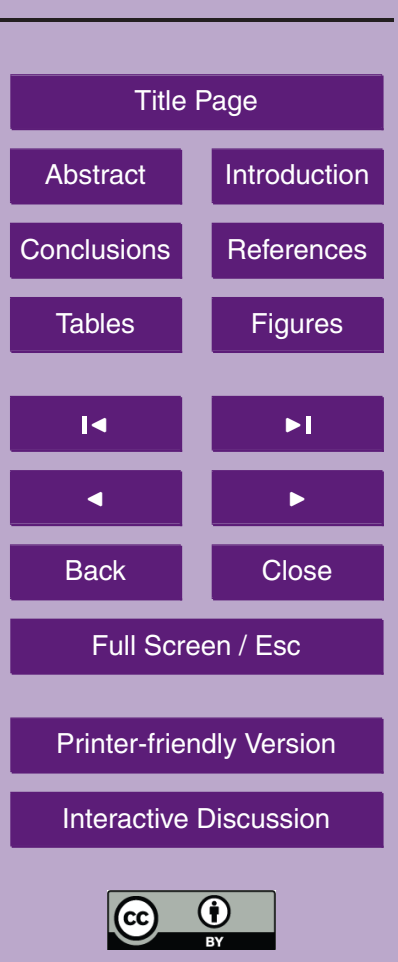
also shows $100 \mathrm{kyr}$ and $400 \mathrm{kyr}$ cycles in the height of peak equilibrium tides on the equator that correspond with known Earth eccentricity cycles Higher Earth eccentricity would increase contrast in the 586 year LG cycle in all seasons, supporting mode changes in both directions. There is a suggestion in Fig. 15 that state changes cluster 5 in periods of high eccentricity, so for example a warm centennial extreme could play a role in breaching ice albedo threshold. This is a possible interaction between forcing in different timescales. Eccentricity will approach zero $27 \mathrm{kyr}$ in the future (Berger et al., 2003), which will eliminate 586 year contrast at that time. But even without such contrast (straight zero gamma lines parallel to the INEX), March tidal forcing will peak overy 586 years.

Steves et al. (1993) investigate the evolution of the Saros and calculate a monotonic improvement in S-D commensurability over the past 5 million years (yielding LGE). Their combined measure of Saros commensurability passed a $1 \%$ residual threshold at $1.8 \mathrm{Ma}$. This trend parallels long term Cenozoic cooling (Zachos et al., 2001), and 15 may have aided equatorial thermocline shoaling in the transition from early Pliocene El Niño (Fedorov et al., 2006). Liesiecki and Raymo (2005) observe a change in ice sheet response to precession at $1.6 \mathrm{Ma}$.

The Holocene altithermal at September perihelion $6050 \mathrm{ka}$ (Kukla and Gavin, 2004) provides an opportunity to access the above forcing when ENSO proxies are available: (1) Thompson et al. (2006) record an Andes "cold snap" at 5,200 ka; (2) After $5,790 \pm 90 \mathrm{ka}$, Sandweiss et al. (1996) observe a transition to temperate Peruvian mollusk assemblages compatible with ENSO variability; (3) After 5,400 ka, Haug et al. (2001) observe a trend towards dry conditions in the Cariaco Basin, with the southward ITCZ shift noted above; (4) After 7,000 ka, Rodbell et al. (1999) find an increased 25 frequency of ENSO storm alluviation in an Ecuadorian alpine lake. These proxies are consistent with the present hypothesis, by which north ITCZ bias weakens after September perihelion, which allows PCC, which leads to an increase in ENSO variability. In comparison, Clement et al. (2000) similarly invoke precessional change in the annual cycle, but propose that it acts by suppressing trade winds in boreal summer,
$6,905-961,2010$

\section{Global cooling by equatorially symmetric La Niña}

J. H. Duke
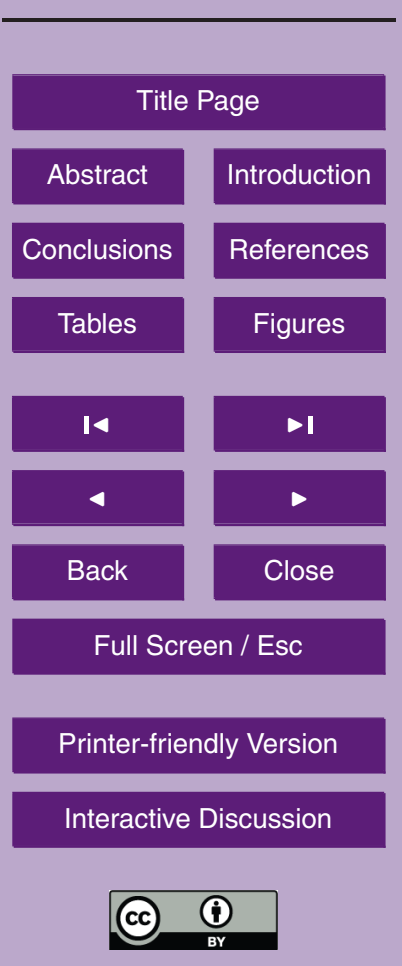
which favors enhanced development of otherwise stochastic warm events (and vice versa in the early Holocene). Alternately, Chiang et al. (2009) advocate a linear response to changes in the extra-tropically forced Pacific Meridional Mode (PMM) (Chiang and Vimont, 2004), but its tropical consequence is ITCZ displacement towards

5 the warmer hemisphere, as proposed here. These studies fundamentally agree that ENSO variability follows trade wind instability, though their model structures trigger it very differently. Trade wind instability leads to eastward surface advection (Picaut et al., 1996) at El Niño onset, which PCC triggers directly. Is PMM related to the Alory and Delcroix (2002) meridional see-saw whose negative expression appeared in $1998 ?$

10 Perihelion at 6,000 ka marked the end of the most recent half precession melt interval, at which time obliquity was $24.1^{\circ}$ and declining. By the precession-obliquity dynamic proposed above, the observed cooling and increase in ENSO activity that followed may be understood as a latent glaciation delayed by high obliquity. Perihelion is now in early January and obliquity is $23.446^{\circ}$, and at the next March perihelion 4 thou15 sand years in the future it will be approximately $23.0^{\circ}$. In the past 3 million years there are 142 January perihelions, of which 12 coincide with declining obliquity between $23.446^{\circ}$ and $23.0^{\circ}$, indicated by solid vertical lines above the LR04 stack in Fig. 15. 10 of these are glacial or at glacial onset. One exception is at 1,686 ka (MIS 59) at low eccentricity analogous to the present (Berger et al., 2003), and the other is at 2,784 ka 20 (MIS G8).

\section{Summary}

A hypothesis is advanced that tidal forcing leverages ENSO dynamics through ITR, providing an external driver that the tropical hypothesis lacks in millennial timescales (Chiang, 2009). Distinguishing the resultant ESLN mode from usual La Niña resolves a number of controversies. The proposed mechanism of ESLN by PCC by ITR and/or ITCZ migration provides a qualitative framework that attempts to integrate global change across timescales. The framework yields striking correlations with the

$6,905-961,2010$

\section{Global cooling by equatorially symmetric La Niña \\ J. H. Duke}

\section{Title Page}

Abstract Introduction Conclusions References

Tables Figures

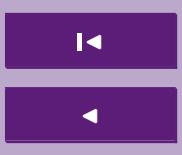
- I

Back

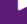

Close

Full Screen / Esc

Printer-friendly Version

Interactive Discussion

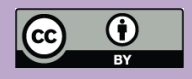


instrument and proxy records, and points to much work required to understand its physics. The idea that climate is influenced by eclipses and/or their related lunar perturbations is plausible if observed to influence the otherwise conservative property of ocean vorticity.

5 As tides are predictable, confirmation of the ITR effect proposed here may provide a means to forecast ENSO that is of great societal value (McPhaden, 2006). Understanding local variations in buoyancy frequency that govern ITR susceptibility is required, probably beginning with the phenomenon of Kelvin fronts (Fedorov and Melville, 2000). An island effect survey of the EUC's passage through the Gilbert Islands at $173^{\circ} \mathrm{E}$ 10 may be informative. Ferrari and Wunsch (2009) conclude, "There is no shortage of problems remaining in the much discussed area of ocean mixing."

Acknowledgements. I thank André Berger for customizing a table of latitude and month specific insolation values which began this inquiry. The assistance of Mitch Berkson in data prepartaion and early discussions with B. Allyn Copp and Irving C. Sheldon, Jr., are also greatly appreci15 ated.

\section{References}

Alory, G. and Delcroix, T.: Interannual sea level changes and associated mass transports in the tropical Pacific from TOPEX/Poseidon data and linear model results (1964-1999), J. Geophys. Res., 107(C10), 3153, doi:10.1029/2001JC001067, 2002.

Barker, S., Diz, P., Vautravers, M. J., Pike, J., Knorr, G., Hall, I. R., and Broecker, W. S.: Interhemispheric Atlantic seesaw response during the last deglaciations, Nature, 457, 10971103, 2009.

Beaufort, L., de Garidel-Thoron, T., Mix, A. C., and Pisias, N.: ENSO-like forcing on oceanic primary production during the Late Pleistocene, Science, 293, 2440-2444, 2001.

25 Beaufort, L., de Garidel-Thoron, T., Linsley, B., Oppo, D., and Buchet, N.: Biomass burning and oceanic primary production estimates in the Sulu Sea area over the last $380 \mathrm{kyr}$ and the East Asian monsoon dynamics, Mar. Geol., 201, 53-65, 2003.

Berger, A.: Long-Term Variations of Daily Insolation and Quaternary Climate Changes, J. Atmos. Sci., 35, 2362-2367, 1978.
$6,905-961,2010$

\section{Global cooling by equatorially symmetric La Niña}

J. H. Duke

\section{Title Page}

Abstract

Introduction

Conclusions

References

Tables

Figures
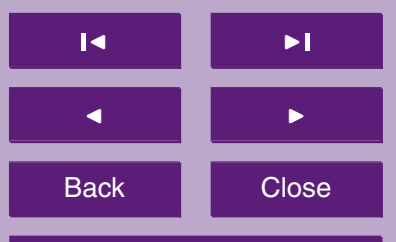

Back

Close

Full Screen / Esc

Printer-friendly Version

Interactive Discussion

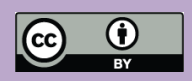


Berger, A. and Loutre, M. F.: Insolation values for the climate of the last 10 million of years, Quaternary Sci. Rev., 10(4), 297-317, 1991.

Berger, A. L., Loutre, M. F., and Crucifix, M.: The Earth's climate in the next hundred thousand years (100 kyr), Surv. Geophys., 24, 117-138, 2003.

5 Berger, A. L. and Loutre, M. F.: Astonomical theory of climate change, J. Phys. IV France, 121, 1-35, doi:10.1051/jp4:2004121001, 2004.

Bond, G. C., Showers, W., Elliot, M., Evans, M., Lotti, R., Hajdas, I., Bonani, G., ans Johnson, S.: The north Atlantic's 1-2 kyr climate rhythm: Relation to Heinrich Events, Dansgaard/Oeschger cycles and the Little Ice Age, Geophysical Monograph 112, American Geophysical Union, 35-58, 1999.

Broecker, W. S.: Mountain Glaciers: Recorders of Atmospheric Water Vapor Content?, Global Biogeochem. Cy., 11(4), 589-597, 1997.

Broecker, W. S.: Does the Trigger for Abrupt Climate Change Reside in the Ocean or in the Atmosphere?, Science, 300, 1519-1522, 2003.

15 Broecker, W. S. and Denton, G. H.: The role of ocean-atmosphere reorganizations in glacial cycles, Geochim. Cosmochim. Acta, 53, 2465-2501, 1989.

Broecker, W. S. and van Donk, J.: Insolation changes, ice volumes, and the 018 record in deep sea cores, Rev. Geophys. Space Phys., 8(1), 169-198, 1970.

Brown, J. M. and Fedorov, A. V.: Estimating the diapycnal transport contribution to warm water volume variations in the tropical Pacific, J. Climate, 23, 221-237, 2010.

Cane, M. A.: Climate change: A role for the tropical Pacific, Science, 282, 59-61, 1998.

Cane, M. A. and Clement, A.: A role for the tropical Pacific coupled ocean-atmosphere system on Milankovitch and millennial timescales, Part II: Global impacts, Geophysical Monograph 112, American Geophysical Union, 373-383, 1999.

Cane, M. A. and Molnar, P.: Closing of the Indonesian seaway as a precursor to east African aridification around 3-4 million years ago, Nature, 411, 157-162, 2001.

Cervany, R. S. and Shaffer, J. A.: The moon and El Niño, Geophys. Res. Lett., 28(1), 25-28, 2001.

Chaves, F. P., Strutton, P. G., Friederich, G. E., Feely, R. A., Feldman, G. C., Foley, D. G., and McPhaden, M. J.: Biological and chemical response of the equatorial Pacific Ocean to the 1997-98 El Niño, Science, 286, 2126-2131,1999.

Chiang, J. C. H.: The tropics in paleoclimate, Annu. Rev. Earth PI. Sc., 37, 263-297, 2009.
$6,905-961,2010$

\section{Global cooling by equatorially symmetric La Niña}

J. H. Duke

\section{Title Page}

Abstract

Introduction

Conclusions

References

Tables

Figures

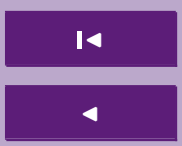

$\rightarrow 1$

Back

$\checkmark$

Close

Full Screen / Esc

Printer-friendly Version

Interactive Discussion

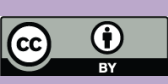


Chiang, J. C. H. and Vimont, D. J.: Analogous Pacific and Atlantic meridional modes of tropical atmosphere-ocean variability, J. Climate, 17, 4141-4158, 2004.

Chiang, J. C. H., Fang, Y., and Chang, P.: Interhemispheric thermal gradient and tropical Pacific climate, Geophys. Res. Lett., 35, L14704, doi:10.1029/2008GL034166, 2008.

5 Chiang, J. C. H., Fang, Y., and Chang, P.: Pacific Climate Change and ENSO Activity in the Mid-Holocene, J. Climate, 22, 923-939, 2009.

Clark, P. U., Webb, R. S., and Keigwin, L. D.: Mechanisms of global climate change at millennial time scales, Geophysical Monograph 112, American Geophysical Union, 1999.

Charlson, R. J., Lovelock, J. E., Andreae, M. O. and Warren, S. G.: Ocean phytoplankton, atmospheric sulphur, cloud albedo and climate, Nature, 326, 655-661, 1987.

Clemens, S. C. and Prell, W. L.: A 350,000 year summer-monsoon multi-proxy stack from the Owen Ridge, northern Arabian Sea, Mar. Geol., 201, 35-51, 2003.

Clemens, S. C.: Millennial-band climate spectrum resolved and linked to centennial-scale solar cycles, Quaternary Sci. Rev., 24, 521-531, 2005.

15 Clement, A. C. and Peterson, L. C.: Mechanisms of abrupt climate change of the last glacial period, Rev. Geophys., 46, RG4002, doi:10.1029/2006RG000204, 2008.

Clement, A., Seager, R., and Cane, M. A.: Orbital control on the El Niño/Southern Oscillation and the tropical climate, Paleoceanography, 14, 441-456, 1999.

Clement, A., Cane, M. A., and Seager, R.: Suppression of El Niño during the mid-Holocene by changes in the Earth's orbit, Paleoceanography, 15(6), 731-737, 2000.

Clement, A., Cane, M. A. and Seager, R.: An Orbitally Driven Tropical Source for Abrupt Climate Change, J. Climate, 14(11), 2369-2375, 2001.

Coale, K. H., Johnson, K. S., Fitzwater, S. E., Gordon, R. M., Tanner, S., Chavez, F. P., Ferioli, L., Sakamoto, C., Rogers, P., Millero, F., Steinberg, P., Nightingale, P., Cooper, D., Cocklan, W. P., Landry, M. R., Constantinou, J., Rollwagen, G., Trasvina, A., and Kudela, R.: A massive phytoplankton bloom induced by an ecosystem-scale iron fertilization experiment in the equatorial Pacific Ocean, Nature, 383, 495-501, 1996.

Cook, E. R., Woodhouse, C. A., Eakin, C. M., Meko, D. M., and Stahle, D. W.: Long term aridity changes in the western united states, Science, 306, 1015-1018, 2004.

30 Duke, J. H.: A Common Mechanism of Multi-timescale Abrupt Global Change, Eos Trans. AGU, 83(47), Fall Meet. Suppl., Abstract PP23C-1485, 2008.

Fang, Y., Chiang, J. C. H., and Chang, P.: Variation of mean sea surface temperature and modulation of El Niño - Southern Oscillation variance during the past 150 years, Geophys.
$6,905-961,2010$

\section{Global cooling by equatorially symmetric La Niña}

J. H. Duke

\section{Title Page}

Abstract

Introduction

Conclusions

References

Tables

Figures
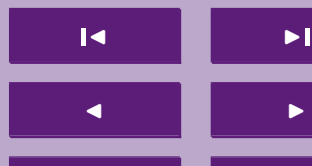

Back

Close

Full Screen / Esc

Printer-friendly Version

Interactive Discussion

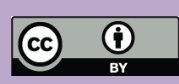


Res. Lett., 35, L08703, doi:10.1029/2007GL033097, 2008.

Fedorov, A. V.: The response of the coupled tropical ocean-atmosphere to westerly wind bursts, Q. J. Roy. Meteorol. Soc., 128, 1-23, 2002.

Fedorov, A. and Melville, W. K.: Kelvin Fronts on the Equatorial Thermocline, J. Phys. Oceanogr., 30, 1692-1705, 2000.

Fedorov, A. V., Dekens, P. S., McCarthy, M., Ravelo, A. C., deMenocal, P. B., Barreiro, M., Pacanowski, R. C., and Philander, S. G.: The Pliocene paradox (mechanisms for a permanent El Niño), Science, 312, 1485-1489, 2006.

Ferrari, R. and Wunsch, C.: Ocean circulation kinetic energy: reservoirs, sources, and sinks, Annu. Rev. Fluid Mech., 41, 253-282, 2009.

Ffield, A. and Gordon, A. L.: Tidal mixing signatures in the Indonesian Seas, J. Phys. Oceanogr., 26, 1924-1937, 1996.

Garrett, C. and Kunze, E.: Internal Tide Generation in the Deep Ocean, Annu. Rev. Fluid Mech., 39, 57-87, 2007.

15 Gergis, J. L. and Fowler, A. M.: A history of ENSO events since A. D. 1525: implications for future climate change, Climatic Change, 92, 343-387, 2009.

Gregg, M. C., Peters, H., Wesson, J. C., Oakey, N. S., and Shay, T. J.: Intensive measurements of turbulence and shear in the equatorial undercurrent, Nature, 318, 140-144, 1985.

Gregg, M. C., Sanford, T. B., and Winkel, D. P.: Reduced mixing from the breaking of internal waves in equatorial waters, Nature, 422, 513-515, 2003.

Grodsky, S. A. and Carton, J. A.: Intense surface currents in the tropical Pacific during 19961998, J. Geophys. Res., 206(C8), 16673-16684, 2001.

Grootes, P. and Stuiver, M.: Oxygen 18/16 variability in Greenland snow and ice with $10^{3}-10^{5}$ year time resolution, J. Geophys. Res., 102(C12), 26455-26470, 1997.

Hanna, E.: Anomalous peak in Antarctic sea-ice area, winter 1998, coincident with ENSO, Geophys. Res. Lett., 28(8), 1595-1598, 2001.

Harrison, M. J. and Hallberg, R. W.: Pacific subtropical cell response to reduced equatorial dissipation, J. Phys. Oceanogr., 38, 1894-1912, 2008.

Haug, G. H., Konrad, A., Hughen, K. A., Sigman, D. M., Peterson, L. C., and Röhl, U.: Southward migration of the intertropical convergence zone through the holocene, Science, 293, 1304-1308, 2001.

Hays, J. D., Imbrie, J., and Shackleton, N. J.: Variations in the earth's orbit: Pacemanker of the ice ages, Science, 194, 1121-1132, 1976.
$6,905-961,2010$

\section{Global cooling by equatorially symmetric La Niña}

J. H. Duke

\section{Title Page}

Abstract

Introduction

Conclusions

References

Tables

Figures
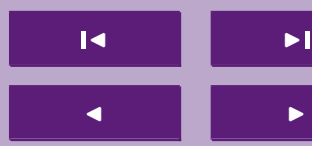

$>1$

Back

$\checkmark$

Close

Full Screen / Esc

Printer-friendly Version

Interactive Discussion

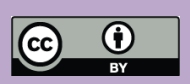


Heming, S. R., Heinrich events: Massive late Pleistocene detritus layers of the North Atlantic and their global climate imprint, Rev. Geophys., 42, RG1005, doi:10.1029/2003RG000128, 2004.

Hendon, H. H., Wheeler, M. C., and Zhang, C.: Seasonal Dependence of the MJO-ENSO Relationship, J. Climate, 20, 531-543, 2007.

Hinnov, L. A., Schulz, M., and Yiou, P.: Interhemispheric space-time attributes of the Dansgaard-Oeschger oscillations between 100 and $0 \mathrm{ka}$, Quaternary Sci. Rev., 21(10), 1213-1228, 2002.

Huybers, P.: Early Pleistocene Glacial Cycles and the Integrated Summer Insolation Forcing, Science, 313, 508-511, 2006.

Huybers, P.: Glacial variability over the last two million years: an extended depth-derived age model, continuous obliquity pacing, and the Pleistocene progression, Quaternary Sci. Rev., 26, 37-55, 2007.

Huybers, P. and Wunsch, C.: Obliquity pacing of the late Pleistocene glacial terminations, Nature, 434, 491-494, 2005.

Huybers, P.: Pleistocene glacial variability as a chaotic response to obliquity forcing, Clim. Past, 5, 481-488, doi:10.5194/cp-5-481-2009, 2009.

Jin, F.-F.: An Equatorial Ocean Recharge Paradigm for ENSO, Part I: Conceptual Model, J. Atmos. Sci., 54, 811-829, 1997a.

20 Jin, F.-F.: An Equatorial Ocean Recharge Paradigm for ENSO, Part II: A Stripped-Down Coupled Model, J. Atmos. Sci., 54, 830-847, 1997b.

Johnson, G. C. and McPhaden, M. J.: Interior pycnocline flow from the subtropical to the equatorial Pacific Ocean, J. Phys. Oceanogr., 29, 3073-3089, 1999.

Johnson, G. C., Sloyan, B. M., Kessler, W. S., and McTaggart, K. E.: Direct measurements of the upper ocean currents and water properties across the tropical Pacific during the 1990s, Prog. Oceanogr., 52, 31-61, 2002.

Johnston, T. M. S., Merrifield, M. A., and Holloway, P. E.: Internal tide scattering at the Line Islands Ridge, J. Geophys. Res., 108(C11), 3365, doi:10.1029/2003JC001844, 2003.

Jones, J. H.: Vertical mixing in the equatorial undercurrent, J. Phys. Oceanogr., 3, 286-196, 286-296, 1973.

Keeling, C. W. and Whorf, T. P.: Possible forcing of global temperature by oceanic tides, P. Natl. Acad. Sci. USA, 94, 8321-8328, 1997.
6, 905-961, 2010

\section{Global cooling by equatorially symmetric La Niña}

J. H. Duke

\section{Title Page}

Abstract

Introduction

Conclusions

References

Tables

Figures
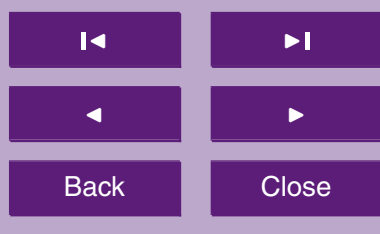

Back

Close

Full Screen / Esc

Printer-friendly Version

Interactive Discussion

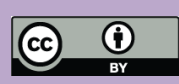


Keeling, C. W. and Whorf, T. P.: The 1,800-year oceanic tidal cycle: A Possible cause of rapid climate change, P. Natl. Acad. Sci. USA, 97(8), 3814-3819, 2000.

Kessler, W. S., Johnson, G. C., and Moore, D. W.: Sverdrup and Nonlinear Dynamics of the Pacific Equatorial Currents, J. Phys. Oceanogr., 33, 994-1008, 2003.

5 Kienast, M., Kienast, S. S., Calvert, S. E., Eglinton, T. I., Mollenhauer, G., François, R., and Mix, A. C.: Eastern Pacific cooling and Atlantic overturning circulation during the last deglaciations, Nature, 443, 846-849, 2006.

Koutavas, A. and Lynch-Stieglitz, J.: Glacial-interglacial dynamics of the eastern equatorial Pacific cold tongue-Intertropical Convergence system reconstructed from oxygen isotope records, Paleoceanography, 18(4), 1089, doi:10.1029/2003PA000894, 2003.

Koutavas, A. and Lynch-Stieglitz, J.: Variability of the marine ITCZ over the eastern Pacific during the past 30,000 years, in: The Hadley Circulation: Present, Past and Future, edited by: Diaz, H. F. and Bradley, R. S., Kluwer Academic Publishers, The Netherlands, 347-369, 2005.

Koutavas, A., Lynch-Stieglitz, J., Marchitto Jr., T. M., and Sachs, J. P.: El Niño-like pattern in ice age tropical Pacific sea surface temperature, Science, 297, 226-230, 2002.

Kukla, G. J., Clement, A. C., Cane, M. A., Gavin, J. E., and Zebiac, Z. E.: Last Interglacial and early glacial ENSO, Quaternary Res., 58, 27-32, 2002.

Kukla, G. J. and Gavin, J. E.: Milankovitch climate reinforcements, Global Planet. Change, 40, 27-48, 2004.

Kukla, J. G. and Gavin, J. E.: Did glacials start with global warming?, Quaternary Sci. Rev., 24, 1547-1557, 2005.

Laskar, J., Robutel, P., Joutel, F., Gastineau, M., Correia, A. C. M., and Levrard, B.: A long term numerical solution for the insolation quantities of the Earth, Astron. Astrophys., 428, $25 \quad 261-285,2004$.

Lindzen, R. S.: Atmospheric Tides, Ann. Rev. Earth PI. Sc., 7, 199-225, 1979.

Lisiecki, L. E. and Raymo, M. E.: A Pliocene-Pleistocene stack of 57 globally distributed benthic $\delta^{18} \mathrm{O}$ records, Paleoceanography, 20, PA1003, doi:10.10289/2004pa001071, 2005.

Lisiecki, L. E. and Raymo, M. E.: Plio-Pleistocene climate evolution: trends and transitions in glacial cycle dynamics, Quaternary Sci. Rev., 26, 56-69, 2007.

Liu, Z., Cleaveland, L. C., and Herbert, T. D.: Early onset and origin of 100-kry cycles in Pleistocene tropical SST records, Earth Planet Sc. Lett., 265, 703-715, 2008.
$6,905-961,2010$

\section{Global cooling by equatorially symmetric La Niña}

J. H. Duke

\section{Title Page}

Abstract

Introduction

Conclusions

References

Tables

Figures
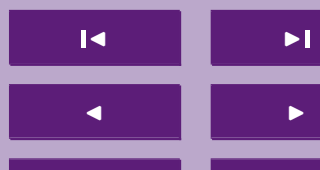

Back

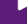

Close

Full Screen / Esc

Printer-friendly Version

Interactive Discussion

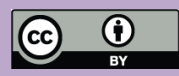


Lyard, F., Lefevre, F., Letellier, T., and Francis, O.: Modelling the global ocean tides: modern insights from FES2004, Ocean Dynam., 56, 394-415, 2006.

Lyle, M. W., Prahl, F. G., and Sparrow, M. A.: Upwelling and productivity changes inferred from a temperature record in the central equatorial Pacific, Nature, 355, 812-815, 1992.

5 Marshall, S. J. and Clark, P. U.: Basal temperature evolution of North American ice sheets and implications for the 100-kyr cycle, Geophys. Res. Lett., 29(24), 2214, doi:10.1029/2002GL015192, 2002.

McPhaden, M. J.: The Equatorial Undercurrent: 100 years of discovery, Eos, 67(40), 7 October, 1986.

10 McPhaden, M. J.: Genesis and evolution of the 1997-98 El Niño, Science, 283, 950-954, 1999.

McPhaden, M. J.: Evolution of the 2002/03 El Niño, B. Am. Meteor. Soc., May, 677-695, 2004.

McPhaden, M. J.: ENSO as an integrating concept in earth science, Science, 314, 1740-1745, 2006.

15 Meeus, J: Mathematical astronomy morsels III, William-Bell, Inc. Richmond, VA, USA, 2004.

Meyers, G. and Donguy, J.-R.: The north equatorial countercurrent and heat storage in the western Pacific Ocean durinh 1982-83, Science, 312, 258-260, 1984.

MICA 2.0: US Naval Observatory multiyear Interactive computer almanac 1800-2050, Willmann-Bell, Inc. Richmond, VA, 1998-2005.

20 Munk, W. and Wunsch, C.: Abyssal recipes II: energetic of tidal and wind mixing, Deep-Sea Res. Pt. I, 45, 1977-2010, 1998.

Munk, W., Dzieciuch, M., and Jayne, S.: Millennial Climate Variability: Is There a Tidal Connection?, J. Climate, 15, 370-385, 2002.

Murray, R. W., Knowlton, C., Leinen, M., Mix, A. C., and Polsky, C. H.: Export production and carbonate dissolution in the central equatorial Pacific Ocean over the last $1 \mathrm{Myr}$, Paleoceanography, 15(6), 570-592, 2000a.

Murray, R. W., Knowlton, C., Leinen, M., Mix, A. C., and Polsky, C. H.: Export production and terrigenous matter in the Central Equatorial Pacific Ocean during interglacial oxygen isotope Stage 11, Global Planet. Change, 24, 59-78, 2000b.

30 Oort, A. H. and Yienger, J. J.: Observed interannual variability in the Hadley Circulation and its connection to ENSO, J. Climate, 9, 2751-2767, 1996.

Ortiz, J. D., O'Connell, S. B., Delvisco, J., Dean, W., Carriquiry, J. D., Marchitto, T., Zheng, Y., and van Geen, A.: Enhanced marine productivity off western North America during warm
$6,905-961,2010$

\section{Global cooling by equatorially symmetric La Niña}

J. H. Duke

\section{Title Page}

Abstract

Introduction

Conclusions

References

Tables

Figures
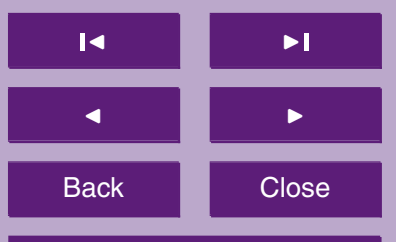

Back

Close

Full Screen / Esc

Printer-friendly Version

Interactive Discussion

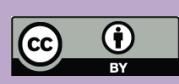


climate intervals of the past 52 k.y., Geology, 32(6), 521-524, 2004.

Paytan, A., Kastner, M., and Chavez, F. P.: Glacial to Interglacial Fluctuations in Productivity in the Equatorial Pacific as Indicated by Marine Barite, Science, 274, 1355-1357, 1996.

Pedersen, T. F.: Increased productivity in the eastern equatorial Pacific during the lat glacial maximum (19,000 to 14,000 B.P.), Geology, 11, 16-19, 1983.

Peeters, F. J. C., Acheson, R., Brummer, G.-J. A., deRuijter, W. P. M., Schneider, R. R., Ganssen, G. M., Ufkes, E., and Kroon, D.: Vigorous exchange between the Indian and Atlantic oceans at the end of the past five glacial periods, Nature, 430, 661-665, 2004.

Philander, S. G. H., Gu, D., Halpern, D., Lambert, G., Lau, N.-C., Li, T., and Pacanowski, R. C.: Why the ITCZ is mostly north of the equator, J. Climate, 9(12), 2958-2972, 1996.

Picaut, J., loualalen, M., Menkes, C., Delcroix, T., and McPhaden, M. J.: Mechanism of the Zonal Displacements of the Pacific Warm Pool: Implications for ENSO, Science, 274, 14861489, 1996.

Pierrehumbert, R. T.: Climate change and the tropical Pacific: the sleeping dragon wakes, P. Natl. Acad. Sci., 97(4), 1355-1358, 2000.

Platzman, G. W.: The atmospheric tide as a continuous spectrum: lunar semidiurnal tide in surface pressure, Meteorol. Atmos. Phys., 38, 70-88, 1988.

Ray, R. D.: Decadal climate variability: Is there a tidal connection?, J. Climate, 20, 3542-3560, 2007.

20 Ray, R. D. and Cartwright, D. E.: Estimates of internal energy fluxes from Topex/Poseidon altimetry: central North Pacific, Geophys. Res. Lett., 28(7), 1259-1263, 2001.

Raymo, M.: The timing of major climate terminations, Paleoceanography, 12(4), 577-585, 1997.

Raymo, M. E. and Nisancioglu, K.: The $41 \mathrm{kyr}$ world: Milankovitch's other unsolved mystery, Paleoceanography, 18(1), 1011, doi:10.1029/2002PA00079, 2003.

Robertson, R. and Field, A.: M2 baroclinic tides in the Indonesian Seas, Oceanography, 18(4), December, 2005.

Rockström, J., Steffen, W., Noone, K., Persson, Å., Chapin III, F. S., Lambin, E., Lenton, T. M., Scheffer, M., Folke, C., Schellnhuber, H., Nykvist, B., De Wit, C. A., Hughes, T., van der Karlberg, L., Corell, R. W., Fabry, V. J., Hansen, J., Walker, B., Liverman, D., Richardson, K., Crutzen, P., and Foley, J.: Planetary boundaries: exploring the safe operating space for humanity, Ecol. Soc., 14(2), 32, 2009.

6, 905-961, 2010

\section{Global cooling by equatorially symmetric La Niña}

J. H. Duke

Title Page

Abstract

Introduction

Conclusions

References

Tables

Figures
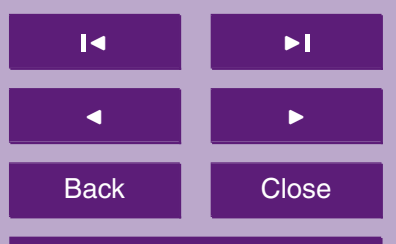

Back

Close

Full Screen / Esc

Printer-friendly Version

Interactive Discussion

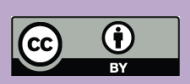


Rodbell, D. T., Seltzer, G. O., Anderson, D. M., Abott, M. B., Enfield, D. B., and Newman, J. H.: An 15,00 year record of El Niñ0-driven alleviation in southwestern Equador, Science, 283, 516-520, 1999.

Ruddiman, W. F.: Orbital changes and climate, Quaternary Sci. Rev., 25, 3092-3112, 2006.

5 Ryan, J. P., Polito, P. S., Strutton, P. G., and Chavez, F. P.: Unusual large-scale phytoplankton blooms in the equatorial Pacific, Prog. Oceangr., 55, 263-285, 2002.

Sandweiss, D. H., Richardson III, J. B., Reitz, E. J., Rollins, H. B., and Maasch, K. A.: Geoarchaeological evidence from Peru for a 5000 years B.P. onset of El Niño, Science, 273, 15311533, 1996.

10 Seager, R., Clement, A. C., and Cane, M. A.: Glacial Cooling in the Tropics: Exploring the roles of Tropspheric Water Vapor, Surface Wind Speed, and Boundary Layer Proceses, J. Atmos. Sci., 57, 2144-2157, 2000.

Seager, R., Battisti, D. S., Yin, J., Gordon, N., Naiki, N., Clement, A. C., and Cane, M. A.: Is the Gulf Stream responsible for Europe's mild winters?, Q. J. Roy. Meteorol. Soc., 128(586), 2563-2586, 2002.

Seager, R., Naik, N., Ting, M., Cane, M. A., Harnik, N., and Kushnir, Y.: Adjustment of the atmospheric circulation to tropical Pacific SST anomalies: Variability of transient eddy propagation in the Pacific-North America sector, Q. J. Roy. Meteorol. Soc., 136(647), 277-296, 2010.

20 Seidel, D. J., Fu, Q., Randel, W. J., and Reichler, T. J.: Widening the tropical belt in a changing climate, Nat. Geosci., 1, 21-24, 2008.

Shaffer, J. A. and Cerveny, R. S.: Long-term equilibrium tides, J. Geophys. Res., 103(C9), 18801-18807, 1998.

Steffensen, J. P., Anderson, K. K., Bigler, M., Clausen, H. B., Dahl-Jensen, D., Fischer, H., Goto-Azuma, K., Hansson, M., Johnsen, S. J., Jouzel, J., Masson-Delmotte, V., Popp, T., Rasmussen, S. O., Röthlisberger, R., Ruthe, U., Stauffer, B., Siggaard-Andersen, M.-L., Sveinbjorndottir, A. E., Svensson, A., and White, J. W. C.: High resolution Greenland ice coredata show abrupt climate change happens in few years, Science, 321, 680-684, 2008.

Steves, B. A.: The cycles of selene, Vista. Ast. S., 41(4), 543-571, 1998.

30 Stott, L., Poulsen, C., Lund, S., and Thunell, R.: Super ENSO and global climate oscillations at millennial time scales, Science, 297, 222-226, 2002.

Sverdrup, H. U.: Wind-driven currents in a baroclinic ocean; with application to the equatorial currents of the eastern Pacific, P. Natl. Acad. Sci., 33, 318-326, 1947.
$6,905-961,2010$

\section{Global cooling by equatorially symmetric La Niña}

J. H. Duke

\section{Title Page}

Abstract

Introduction

Conclusions

References

Tables

Figures
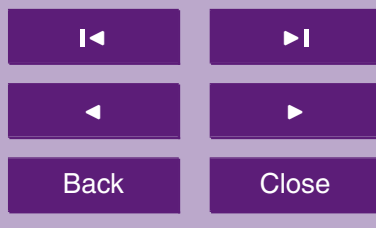

Back

Close

Printer-friendly Version

Interactive Discussion

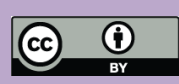


Takahashi, T., Sutherland, S. C., Sweeney, C., Poisson, A., Metzl, N., Tilbrook, B., Bates, N., Wanninkhof, R., Feely, R. A., Sabine, C., Olafsson, J., and Nojiri, Y.: Global sea-air $\mathrm{CO}_{2}$ flux based on climatological surface ocean $p \mathrm{CO}_{2}$, and seasonal biological and temperature effects, Deep-Sea Res. Pt. II, 49, 1601-1622, 2002.

5 Takahashi, K. and Battisti, D. S.: Processes Controlling the Mean Tropical Pacific Precipitation Pattern, Part I: The Andes and the Eastern Pacific ITCZ, J. Climate, 20, 3434-3451, 2007.

Tang, Y. and Yu, B.: MJO and its relationship to ENSO, J. Geophys. Res., 113, D14106, doi:10.1029/2007JD009230, 2008.

Taylor, K. C., Lamorey, G. W., Doyle, G. A., Alley, R. B., Grootes, P. M., Mayewski, P. A., White, J. W. C., and Barlow, L. K.: The "flickering switch" of late Pleistocene climate change, Nature, 361, 432-436, 1993.

Thompson, L. G., Moseley-Thompson, E., Brecher, H., Davis, M., Leon, B., Les, D., Lin, P. N., Mashoitta, T., and Moutain, K.: Abrupt tropical climate change: Past and present, P. Natl. Acad. Sci., 103(28), 10536-10543, 2006.

15 Timmermann, A., Lorenz, S. J., An, S.-I., Clement, A., and Xie, S.-P.: The Effect of Orbital Forcing on the Mean Climate and Variability of the Tropical Pacific, J. Climate, 20(16), 41474159, 2007a.

Timmermann, A., Okumura, Y., An, S.-I., Clement, A., Dong, B., Guilyardi, E., Hu, A., Jungclaus, J. H., Renold, M., Stocker, T. F., Stouffer, R. J., Sutton, R., Xie, S.-P., and Yin, J.: The influence of a weakening of the Atlantic meridional overturning circulation on ENSO, J. Climate, 20, 4899-4919, 2007b.

Toggweiler, J. R., Russel, J. L., and Carson, S. R.: Midlatitude westerlies, atmospheric $\mathrm{CO}_{2}$, and climate change during the ice ages, Paleoceanography, 21, PA2005, doi:10.1029/2005PA001154, 2006.

Trenberth, K. E. and Stepaniak, D. P.: Indices of El Niño evolution, J. Climate, 14, 1697-1701, 2001.

Trend-Staid, M. and Prell, W. L.: Sea surface temperature at the Last Glacial Maximum: A reconstruction using the modern analog technique, Paleoceanography, 17(4), 1065, doi:10.1029/2000PA000506, 2002.

30 Treolar, N. C.: Luni-solar tidal influences on climate variability, Int. J. Climatol., 22, 1527-1542, 2002.
$6,905-961,2010$

\section{Global cooling by equatorially symmetric La Niña}

J. H. Duke

\section{Title Page}

Abstract

Introduction

Conclusions

References

Tables

Figures
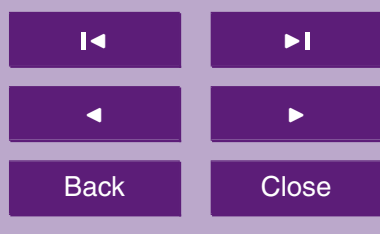

Back

Close

Full Screen / Esc

Printer-friendly Version

Interactive Discussion 
Turner, S. M., Nightingale, P. D., Spokes, L. J., Liddicoat, M. I., and Liss, P. S.: Increased dimethyl sulphide concntrations in sea water from in situ iron enrichment, Nature, 383, 513517, 1996.

Van den Bergh, G.: Periodicity and variability of solar (and lunar) eclipses, H. D. Tjeenk Willink 5 \& Zoon N. V., Haarlem, 1955.

Vecchi, G. A.: The Termination of the 1997-1998 El Niño, Part II: Mechanism of Atmospheric Change, J. Climate, 19, 2647-2664, 2006.

Wang, B. and Wang, Y.: Dynamics of the ITCZ-equatorial cold tongue complex and causes of the latitudinal climate asymmetry, J. Climate, 12, 1830-1847, 1999.

Wang, C. and Picaut, J.: Understanding ENSO physics - A review, in Earth's Climate: The Ocean-Atmosphere Interaction, AGU Geophys. Monogr. Ser., 147, 21-48, 2004.

Wang, X., Auler, A. S., Edwards, R. L., Cheng, H., Cristalli, P. S., Smart, P. L., David, A., Richards, D. A., and Shen, C.-C.: Wet periods in northeastern Brazil over the past $210 \mathrm{kyr}$ linked to distant climate anomalies, Nature, 432, 740-743, 2004.

Wells, M. L., Vallis, G. K., and Silver, E. A.: Tectonic Processes in Papua New Guinea and past productivity in the eastern equatorial Pacific Ocean, Nature, 398, 601-604, 1999.

Wood, F.: Tidal dynamics, Reidel, Dordrecht, The Netherlands, 1986.

Wyrtki, K. and Kilonsky, B.: Mean Water and Current Structure during the Hawaii-to-Tahiti Shuttle Experiment, J. Phys. Oceanogr., 14, 242-254, 1984.

Wyrtki, K.: Water Displacements in the Pacific and the genesis of El Niño cycles, J. Geophys. Res., 90(C4), 7129-7130, 1985.

Xie, S.-P. and Philander, S. G. H.: A coupled ocean-atmosphere model of relevance to the ITCZ in the eastern Pacific, Tellus A, 46, 340-350, 1994.

Xie, S.-P.: The shape of continents, air-sea interaction, and the rising branch of the Hadley Circulation, in: The Hadley Circulation: Present, Past and Future, edited by: Diaz, H. F. and Bradley, R. S., Kluwer Academic Publishers, The Netherlands, 121-152, 2005.

$\mathrm{Yu}, \mathrm{X}$. and McPhaden, M. J.: Seasonal Variability in the Equatorial Pacific, J. Phys. Oceanogr., 29, 925-947, 1999.

$\mathrm{Yu}, \mathrm{X}$. and McPhaden, M. J.: Dynamical Analysis of Seasonal and Interannual Variability in the $30 \quad$ Equatorial Pacific, J. Phys.l Oceanogr., 29, 2350-2369, 1999.

Zachos, J., Pagani, M., Sloan, L., Thomas, E., and Billups, K.: Trends, rhythms, and aberrations in global climate $65 \mathrm{Ma}$ to present, Science, 292, 686-693, 2001.
$6,905-961,2010$

\section{Global cooling by equatorially symmetric La Niña}

J. H. Duke

\section{Title Page}

Abstract

Introduction

Conclusions

References

Tables

Figures
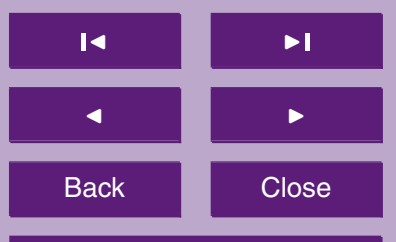

Back

Close

Full Screen / Esc

Printer-friendly Version

Interactive Discussion 


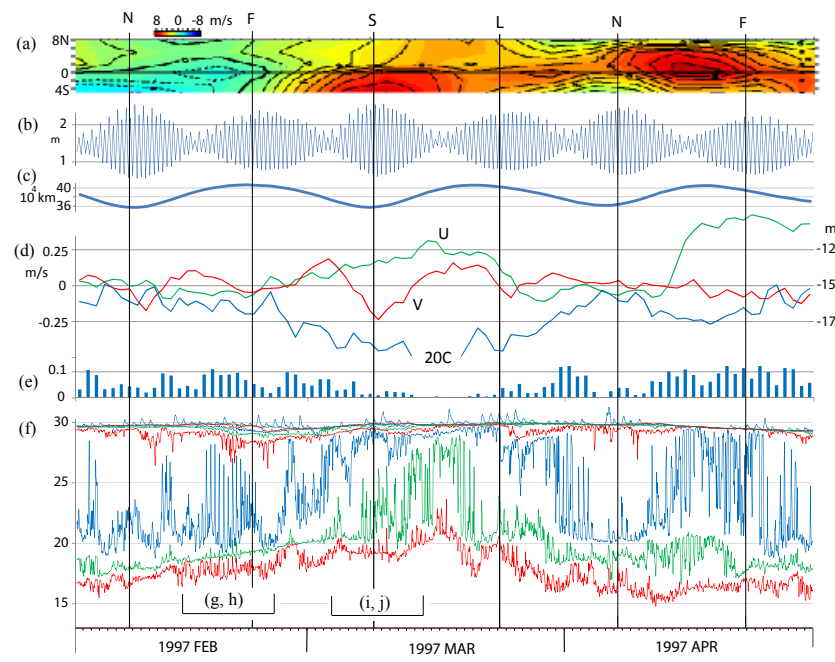

6, 905-961, 2010

\section{Global cooling by equatorially symmetric La Niña}

J. H. Duke

Title Page

Abstract

Introduction

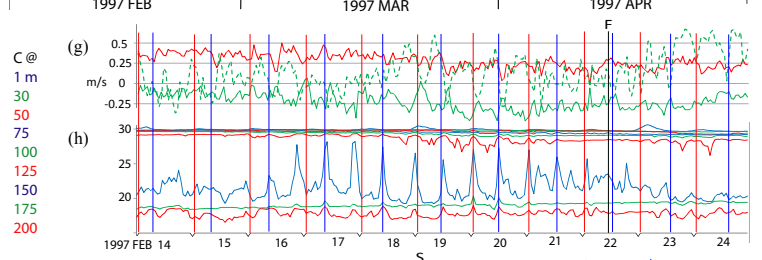

(i) 0.25 thm

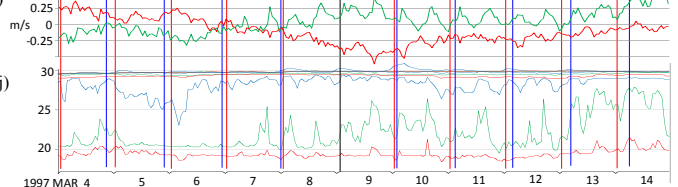

Conclusions

References

Tables

Figures
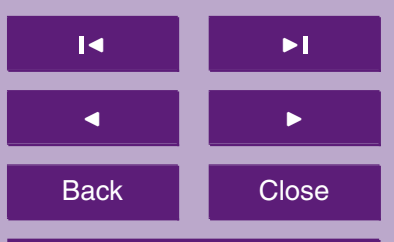

Back

Close

Full Screen / Esc

Fig. 1. February to April 1997:(a) $165^{\circ} \mathrm{E}$ Lat-Time plot of 5 day mean zonal wind anomaly, (b) Height of tide above datum at Marshal Islands, (c) Lunar distance. At $0^{\circ}, 165^{\circ} \mathrm{E}$ : (d) Daily $30-245 \mathrm{~m}$ average zonal (green) and meridional (red) current and $20^{\circ} \mathrm{C}$ isotherm (blue, right scale), (e) Daily coefficient of variation (standard deviation/mean) of one hour $150 \mathrm{~m}$ sea temperature, (f) One hour resolution subsurface temperatures at depths shown, (g) One hour resolution detail of zonal current at $150 \mathrm{~m}$ (solid green), $100 \mathrm{~m}$ (dashed green) and meridional current at $100 \mathrm{~m}$ (red), (h) Detail of (f), (i) Detail as in (g), (j) Detail of (f), with local meridian passage of moon (blue) and sun (red). Sources: TAO Project office PMEL/NOAA, CO-OPS/NOAA, MICA. 


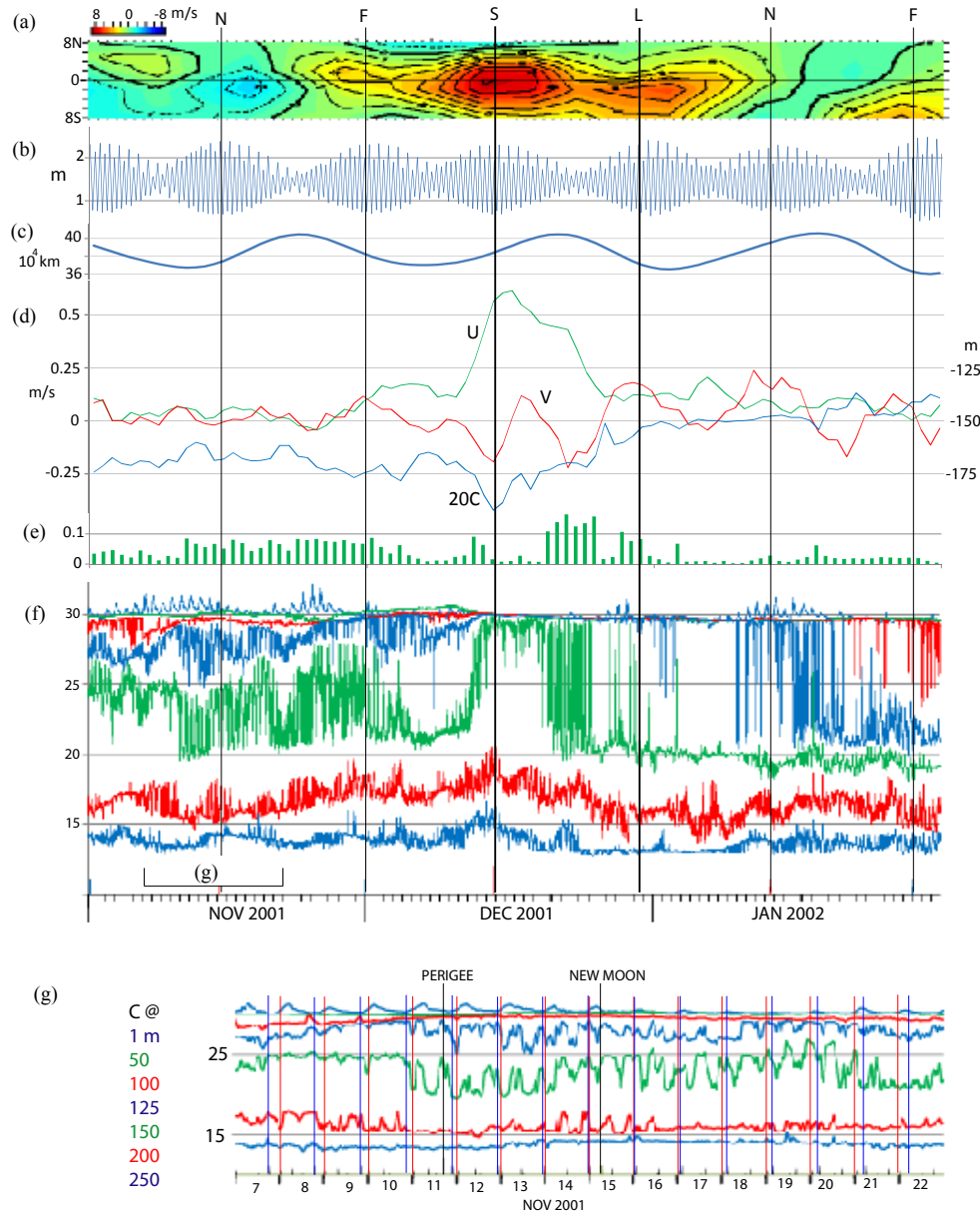

Fig. 2. November 2001 to January 2002: (a)-(e) as in Fig. 1, (f) Ten minute resolution subsurface temperatures at depths shown, (g) Detail of (f), with local meridian passage of moon (blue) and sun (red). Sources: TAO Project office PMEL/NOAA, CO-OPS/NOAA, MICA.
6, 905-961, 2010

\section{Global cooling by equatorially symmetric La Niña}

J. H. Duke

Title Page

\begin{tabular}{|c|c|}
\hline Abstract & Introduction \\
\hline Conclusions & References \\
\hline Tables & Figures \\
\hline I4 & $\bullet$ \\
\hline 4 & $\triangleright$ \\
\hline Back & Close \\
\hline Full Screen / Esc \\
\hline
\end{tabular}

Printer-friendly Version

Interactive Discussion

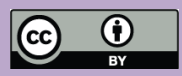


6, 905-961, 2010

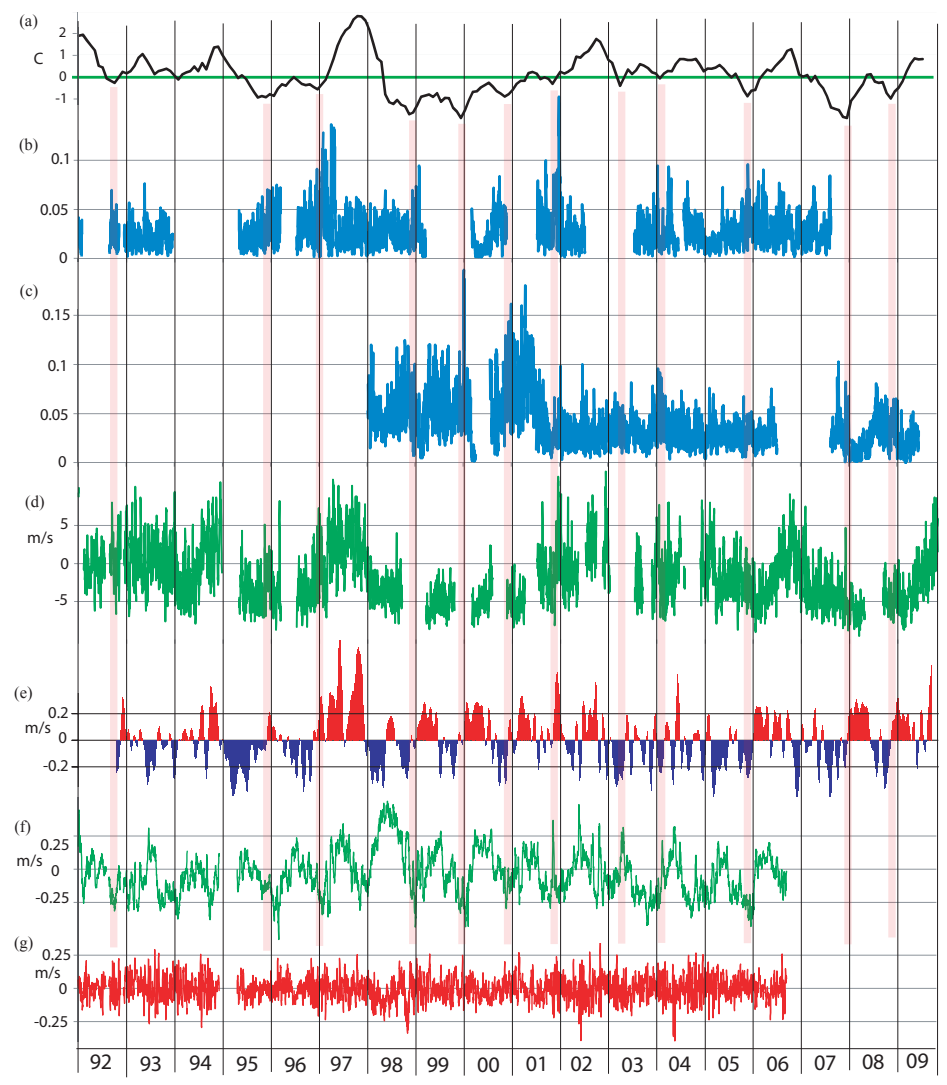

\section{Global cooling by equatorially symmetric La Niña}

J. H. Duke

\section{Title Page}

\begin{tabular}{|c|c|}
\hline Abstract & Introduction \\
\hline Conclusions & References \\
\hline Tables & Figures \\
\hline I4 & $\bullet$ \\
\hline 4 & $\triangleright$ \\
\hline Back & Close \\
\hline Full Screen / Esc \\
\hline
\end{tabular}

Printer-friendly Version

Interactive Discussion $0.5^{\circ} \mathrm{S} \times 170^{\circ} \mathrm{W}-120^{\circ} \mathrm{W}$, (f) Daily $30-245 \mathrm{~m}$ average currents at $0^{\circ}, 165^{\circ} \mathrm{E}$ zonal (green) and meridional (red). Sources: Climate Prediction Center/NOAA, TAO Project office PMEL/NOAA, OSCAR Project Office (Bonjean et al., 2002). 


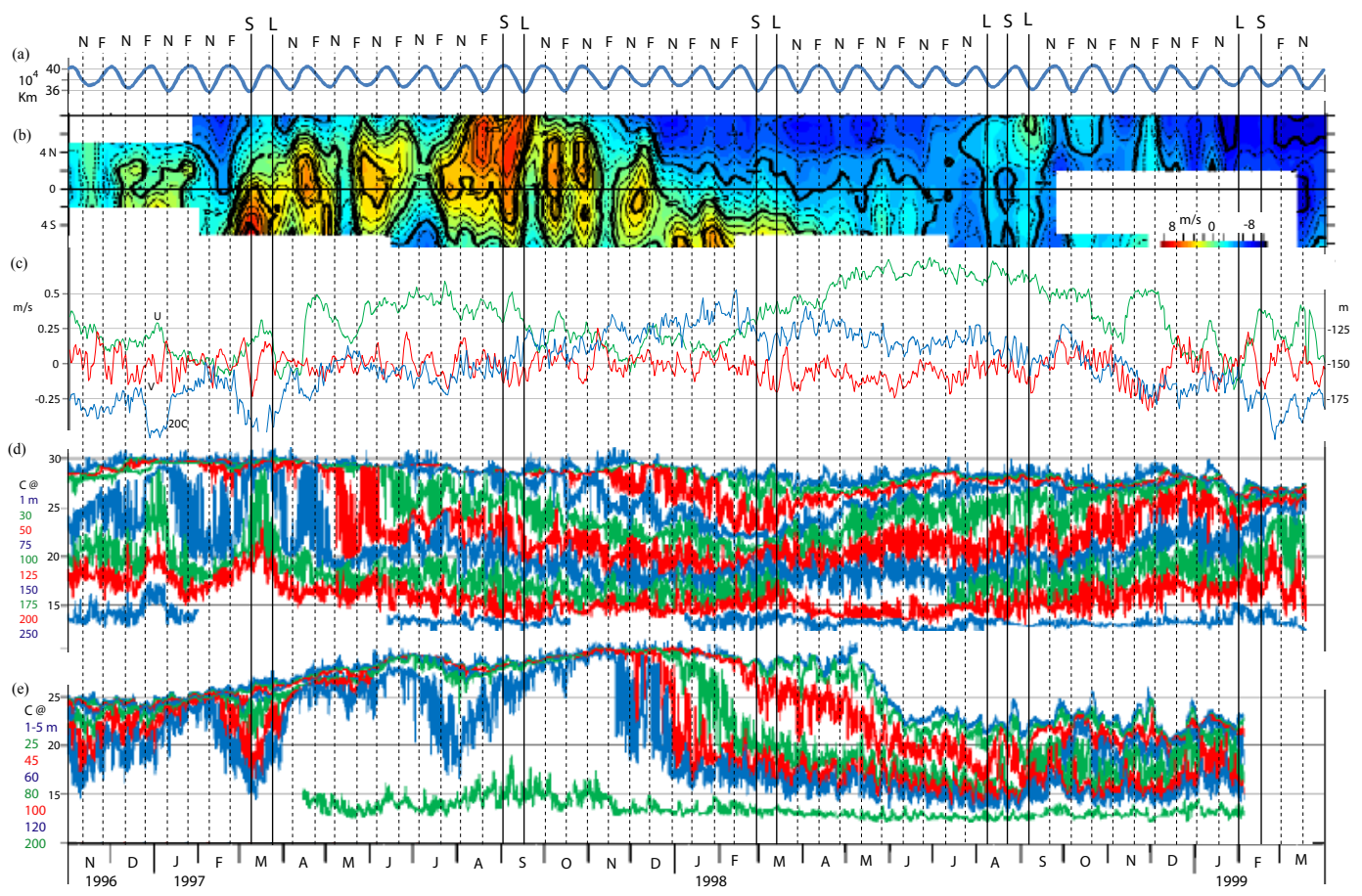

Fig. 4. November 1996 to June 1997: (a) Lunar distance, (b) $165^{\circ} \mathrm{E}$ Lat-Time plot of 5 day mean zonal wind anomaly, (c) Daily $30-245 \mathrm{~m}$ average currents at $0^{\circ}, 165^{\circ} \mathrm{E}$ zonal (green), meridional (red), and $20^{\circ} \mathrm{C}$ isotherm (blue, right scale), (d) One hour resolution subsurface temperatures at $0^{\circ}, 165^{\circ} \mathrm{E}$ at depths shown, (e) As in (d) at $0^{\circ}, 140^{\circ} \mathrm{W}$. Sources: TAO Project office PMEL/NOAA, MICA.
6, 905-961, 2010

\section{Global cooling by equatorially symmetric La Niña}

J. H. Duke

Title Page

\begin{tabular}{|c|c|}
\hline Abstract & Introduction \\
\hline Conclusions & References \\
\hline Tables & Figures \\
\hline I4 & $\bullet$ \\
\hline 4 & $\triangleright$ \\
\hline Back & Close \\
\hline Full Screen / Esc \\
\hline
\end{tabular}

Printer-friendly Version

Interactive Discussion

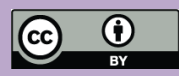




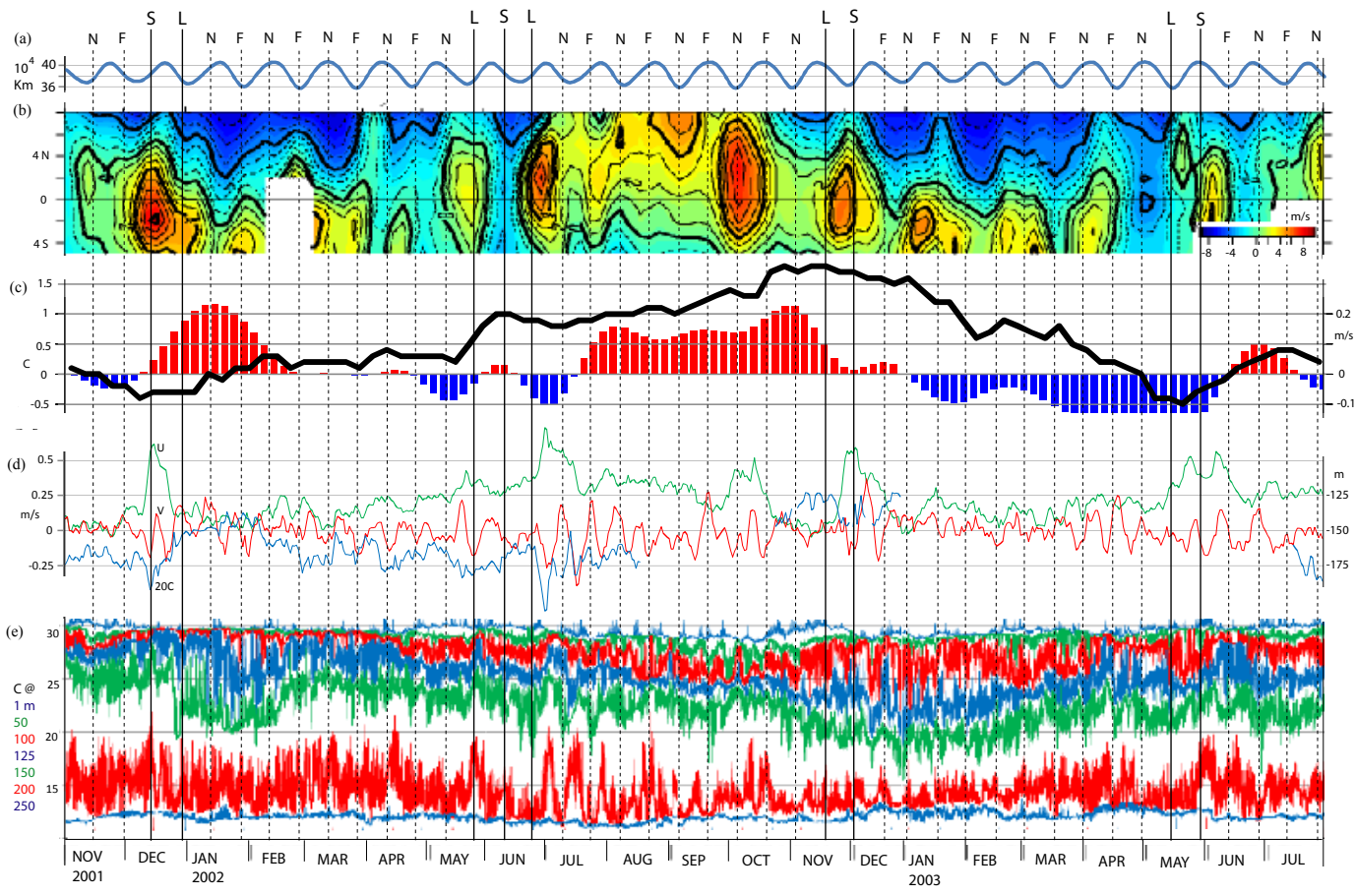

Fig. 5. November 2001 to July 2003: (a), (b) As in Fig. 4, (c) Weekly Niño 3.4 index (black) and 5 day average zonal surface current within $0.5^{\circ} \mathrm{N}-0.5^{\circ} \mathrm{S} \times 170^{\circ} \mathrm{W}-120^{\circ} \mathrm{W}$ (right scale), (d) Daily $30-245 \mathrm{~m}$ average currents at $0^{\circ}, 165^{\circ} \mathrm{E}$ : zonal (green), meridional (red), and $20^{\circ} \mathrm{C}$ isotherm (blue, right scale), (e) Ten minute resolution subsurface temperatures at $0^{\circ}, 165^{\circ} \mathrm{E}$ at depths shown. Sources: TAO Project office PMEL/NOAA, MICA.
$6,905-961,2010$

\section{Global cooling by equatorially symmetric La Niña}

J. H. Duke

Title Page

\begin{tabular}{|c|c|}
\hline Abstract & Introduction \\
\hline Conclusions & References \\
\hline Tables & Figures \\
\hline I & \multicolumn{1}{|c|}{} \\
\hline $\mathbf{A}$ & $\triangleright$ \\
\hline Back & Close \\
\hline Full Screen / Esc
\end{tabular}

Printer-friendly Version

Interactive Discussion

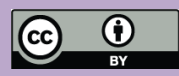




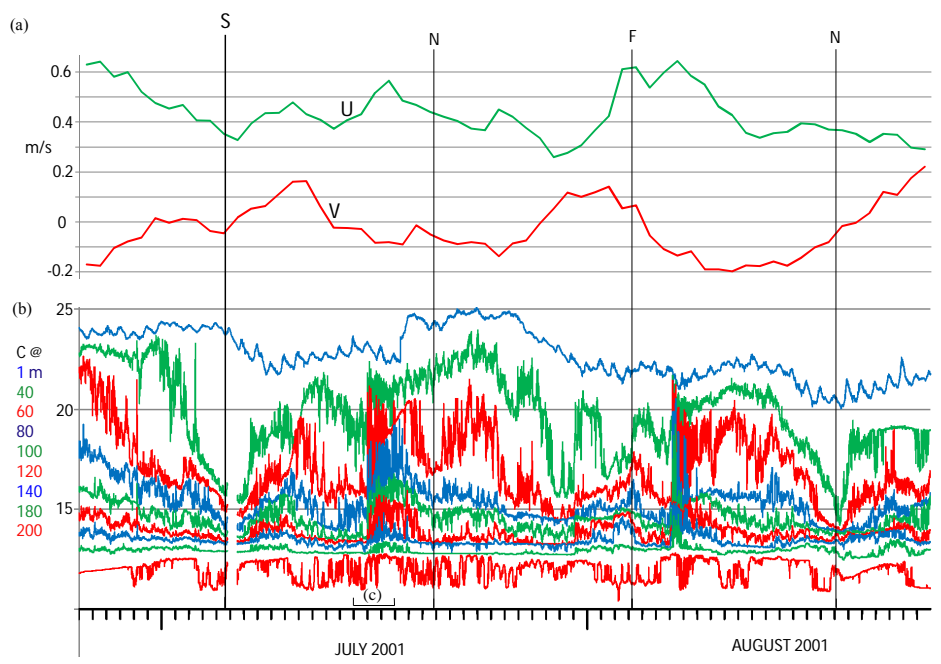

6, 905-961, 2010

\section{Global cooling by equatorially symmetric La Niña}

J. H. Duke

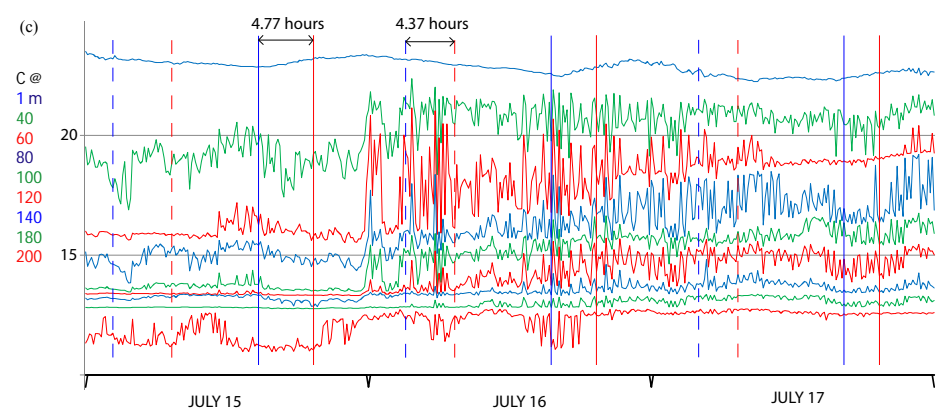

Fig. 6. 25 June to 25 August 2001: (a) Daily $30-245 \mathrm{~m}$ average currents at $0^{\circ}, 165^{\circ} \mathrm{E}$ zonal (green), meridional (red), (b) Ten minute resolution subsurface temperatures at $0^{\circ}, 110^{\circ} \mathrm{W}$ at depths shown, (c) Detail of (b) with local meridian passage of moon (solid blue), moon antipode (dashed blue), sun (solid red), and sun antipode (dashed red). Sources: TAO Project office PMEL/NOAA, MICA.

Title Page

\section{Abstract}

Introduction

Conclusions

References

Tables

Figures
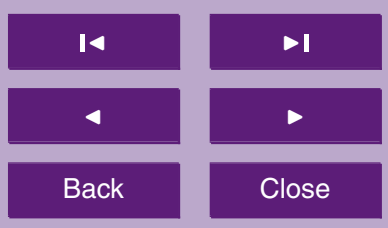

Full Screen / Esc

Printer-friendly Version

Interactive Discussion

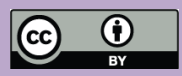




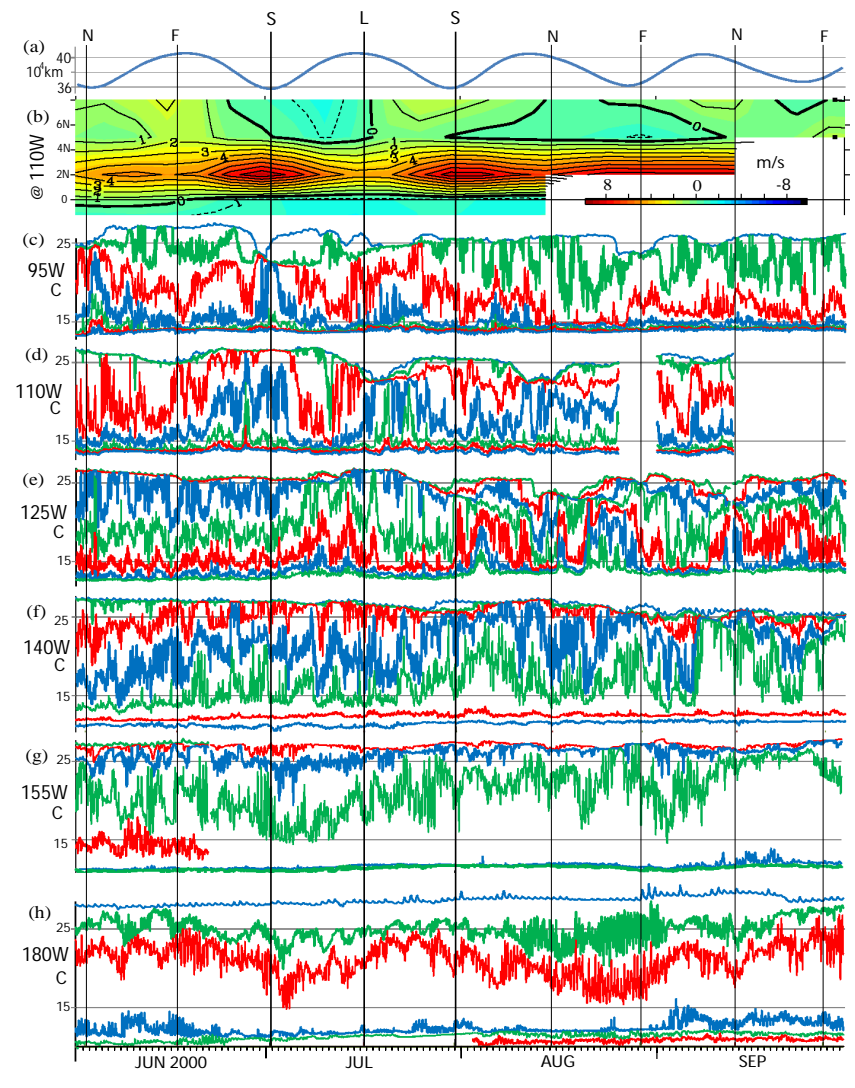

Fig. 7. June to September 2000: (a) Lunar distance, (b) $110^{\circ} \mathrm{W}$ Lat-Time plot of 5 day mean zonal wind anomaly. Subsurface temperatures at $2^{\circ} \mathrm{N}$ and: (d) $95^{\circ} \mathrm{W}$, (e) $110^{\circ} \mathrm{W}$, (f) $125^{\circ} \mathrm{W}$ at $1,40,60,80,100,120$, and $140 \mathrm{~m},(\mathrm{~g}) 140^{\circ} \mathrm{W}$ at $1,60,80,100,120,180$, and $300 \mathrm{~m}$, (h) $155^{\circ} \mathrm{W}$ at $1,75,100,125,150,200$, and $250 \mathrm{~m}$, (h) $180^{\circ}$ at $1,125,150,200,250,300$, and $500 \mathrm{~m}$. Sources: TAO Project office PMEL/NOAA, MICA.
6, 905-961, 2010

\section{Global cooling by equatorially symmetric La Niña}

J. H. Duke

\section{Title Page}

\begin{tabular}{|c|c|}
\hline Abstract & Introduction \\
\hline Conclusions & References \\
\hline Tables & Figures \\
\hline I4 & $\bullet$ \\
\hline 4 & $\bullet$ \\
\hline Back & Close \\
\hline Full Screen / Esc \\
\hline
\end{tabular}

Printer-friendly Version

Interactive Discussion

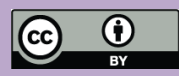




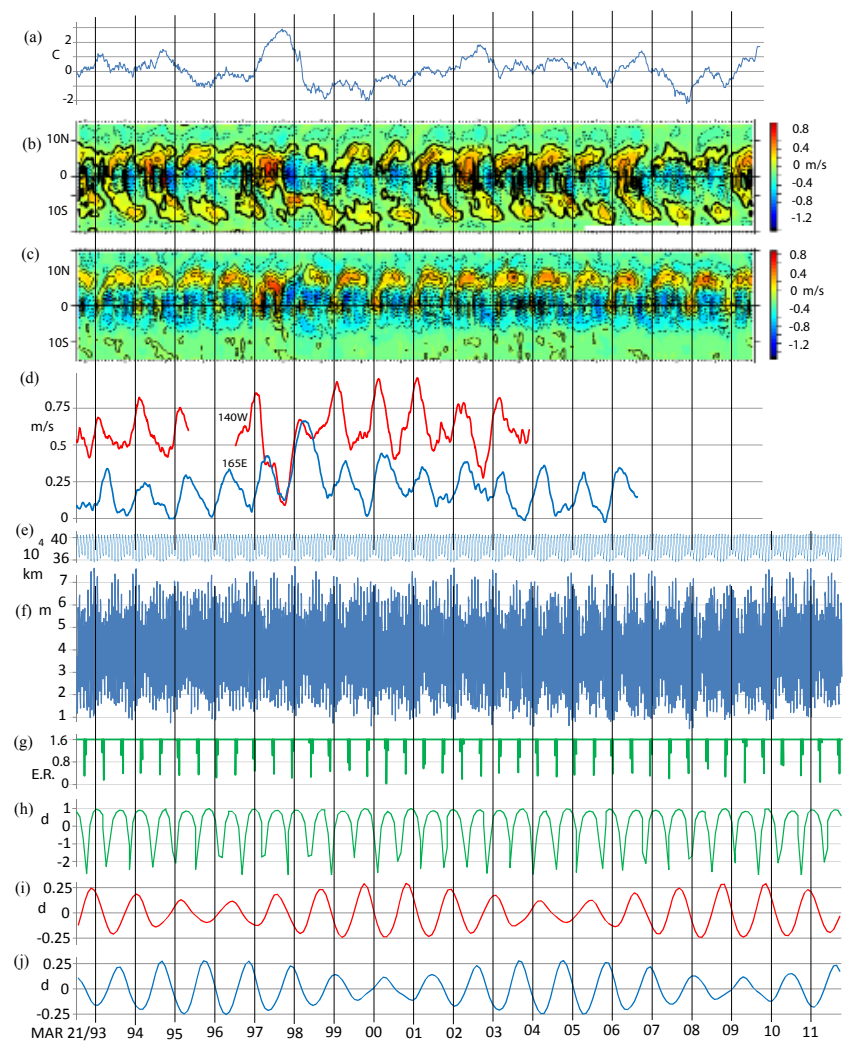

Fig. 8. 1993 to 2011: (a) Weekly Niño 3.4 index. Lat-Time plot of 5 day average zonal surface current at (b) $165^{\circ} \mathrm{E}$ and (c) $140^{\circ} \mathrm{W}$, (d) 90 day running average $30-245 \mathrm{~m}$ average zonal current at $165^{\circ} \mathrm{E}$ (blue) and $140^{\circ} \mathrm{W}$ (red), (e) Lunar distance, (f) Daily tide displacement (see text) at Marshall Islands, (g) Eclipse gamma. Sequential deviations from: (h) mean anomalistic month, (i) mean synodic month new moon to new moon, (j) mean synodic month full moon to full moon. Sources: CPC/NOAA, OSCAR Project Office (Bonjean et al., 2002), TAO Project office PMEL/NOAA, MICA, CO-OPS/NOAA.
6, 905-961, 2010

\section{Global cooling by equatorially symmetric La Niña}

J. H. Duke

\section{Title Page}

\begin{tabular}{|c|c|}
\hline Abstract & Introduction \\
\hline Conclusions & References \\
\hline Tables & Figures \\
\hline I & \multicolumn{1}{|c|}{} \\
\hline 4 & - \\
\hline Back & Close \\
\hline Full Screen / Esc \\
\hline
\end{tabular}

Printer-friendly Version

Interactive Discussion

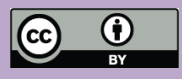




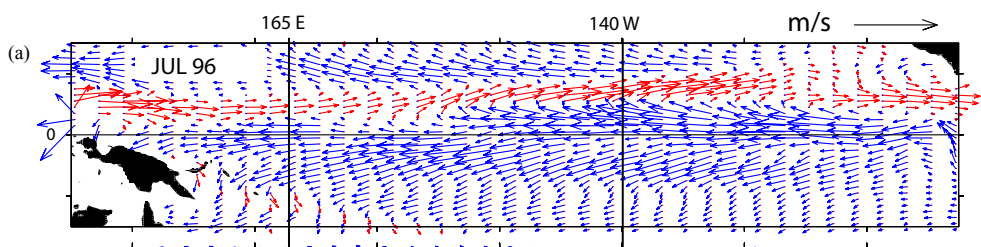

(b)
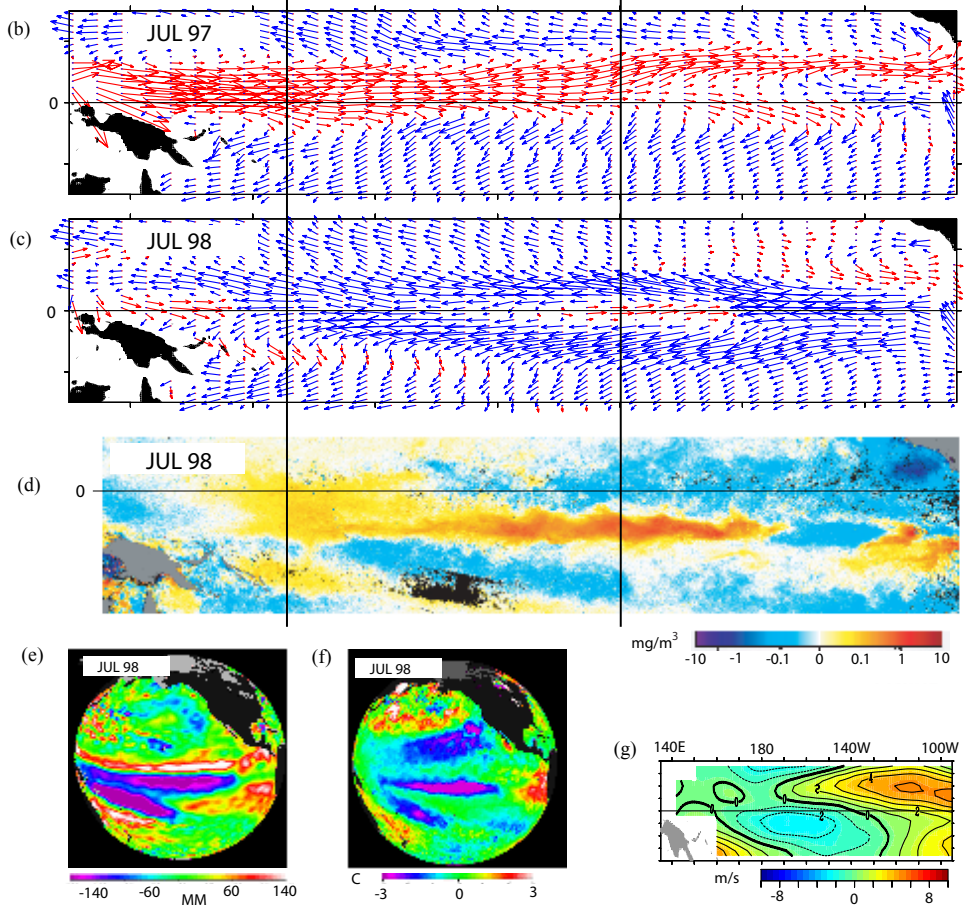

Fig. 9. Mean July surface currents for (a) 1996, (b) 1997, (c) 1998. Mean July 1998: (d) Chlorophyll anomaly, (e) Sea surface height anomaly, (f) Sea surface temperature anomaly, (g) Meridional wind. Sources: OSCAR Project Office (Bonjean et al., 2002), SeaWiFS Project/NASA, TOPEX/Poseidon, TAO Project office PMEL/NOAA.
6, 905-961, 2010

\section{Global cooling by} equatorially symmetric La Niña

J. H. Duke

\section{Title Page}

\begin{tabular}{c|c}
\hline Abstract & Introduction \\
\hline Conclusions & References \\
\hline Tables & Figures \\
\hline I4 & - I \\
\hline 4 & $\bullet$ \\
\hline Back & Close \\
\hline Full Screen / Esc \\
\hline
\end{tabular}

Printer-friendly Version

Interactive Discussion

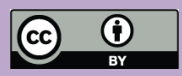




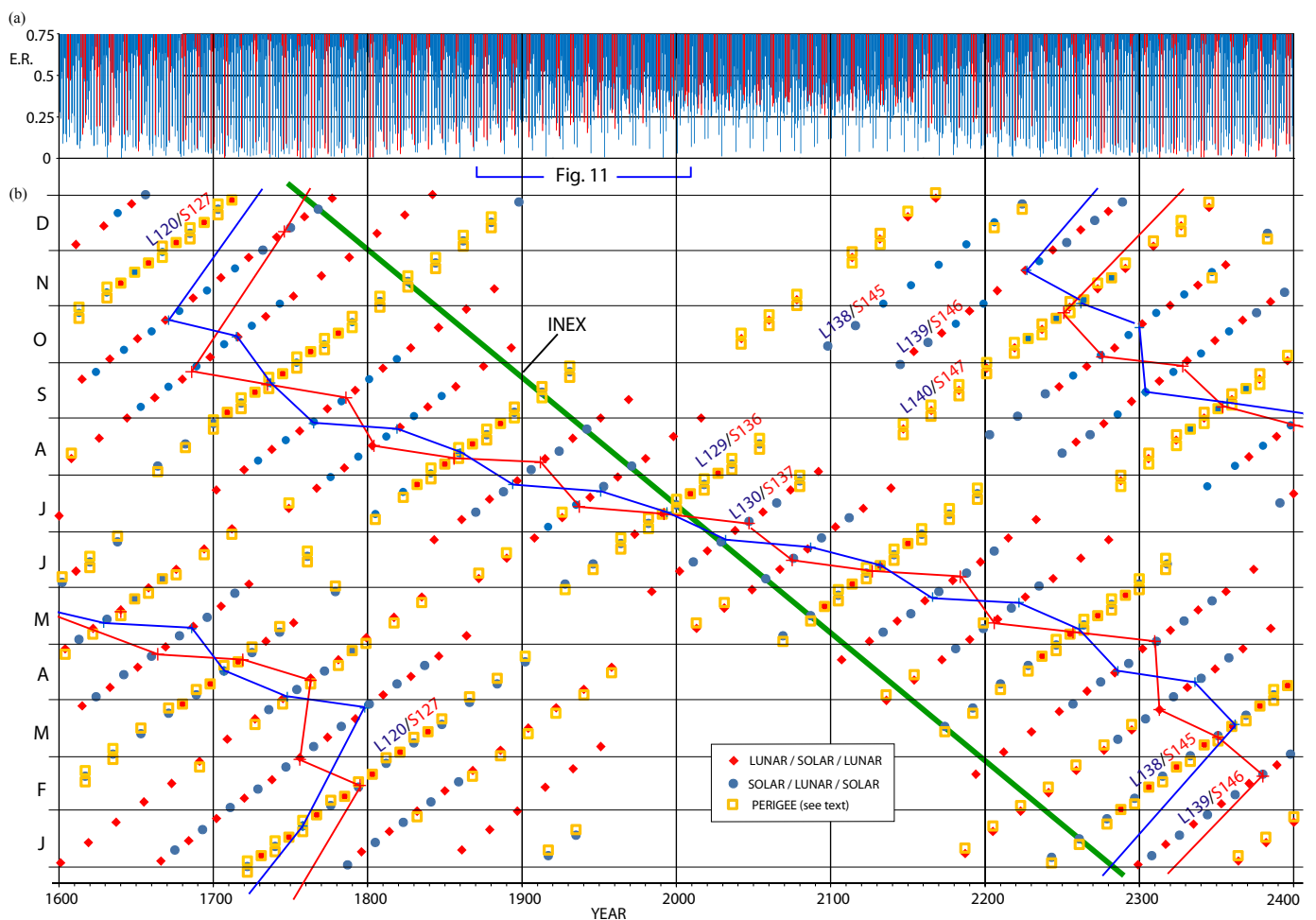

Fig. 10. 1600 to 2400: (a) Absolute value $\gamma<0.75$, (b) Day-year plot of $L G$ event distribution (see text). Sources: Fred Espenak GSFC/NASA, John Walker Lunar Perigee and Apogee Calculator (www.fourmilab.ch/earthview/pacalc).
6, 905-961, 2010

\section{Global cooling by equatorially symmetric La Niña}

J. H. Duke

Title Page

Abstract

Introduction

Conclusions

References

Tables

Figures
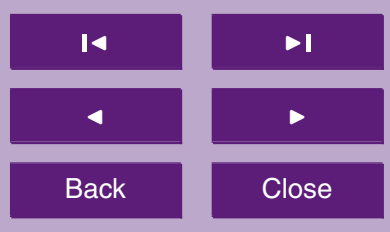

Full Screen / Esc

Printer-friendly Version

Interactive Discussion

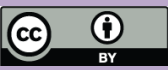


(a)

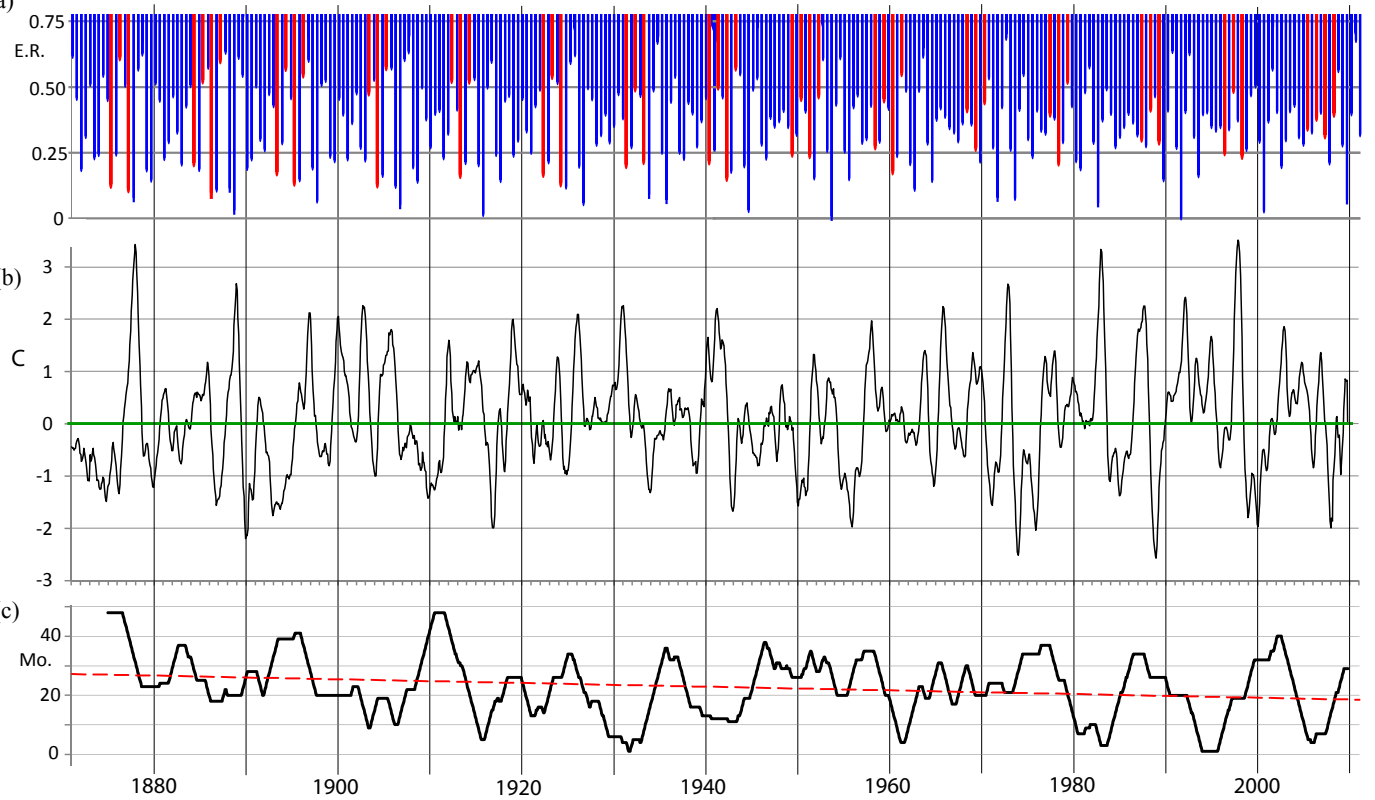

Fig. 11. 1870 to 2010: (a) Absolute value $\gamma<0.75$, (b) Monthly Niño 3.4 anomaly, (c) 48 month running sum of months with negative Niño 3.4 anomaly. Source: Fred Espenak GSFC/NASA, Trenberth and Stepaniak, 2001, CPC/NOAA.
6, 905-961, 2010

\section{Global cooling by equatorially symmetric La Niña}

J. H. Duke

\section{Title Page}

\begin{tabular}{|c|c|}
\hline Abstract & Introduction \\
\hline Conclusions & References \\
\hline Tables & Figures \\
\hline I & $\checkmark$ \\
\hline 4 & $\bullet$ \\
\hline Back & Close \\
\hline Full Screen / Esc \\
\hline
\end{tabular}

Printer-friendly Version

Interactive Discussion

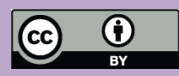




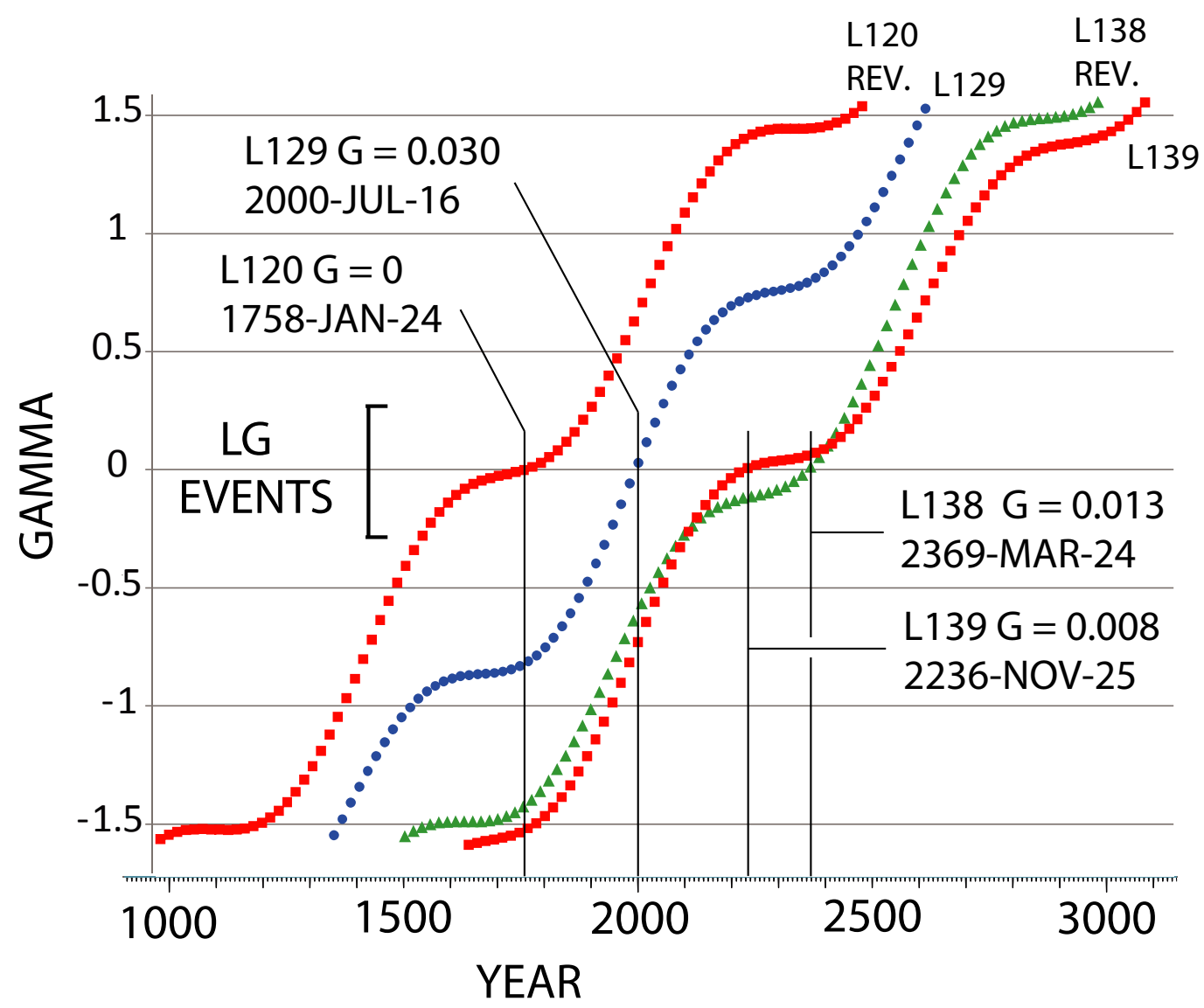

Fig. 12. Absolute value of gamma vs. time for lunar Saros series $L 120, L 129, L 138$, and L139. The sign of L120 and L128 is reversed. Source: Fred Espenak, NASA/GSFC.
6, 905-961, 2010

\section{Global cooling by} equatorially symmetric La Niña

J. H. Duke

Title Page

\begin{tabular}{|c|c|}
\hline Abstract & Introduction \\
\hline Conclusions & References \\
\hline Tables & Figures \\
\hline I4 & $\bullet$ \\
\hline 4 & $\triangleright$ \\
\hline Back & Close \\
\hline Full Screen / Esc \\
\hline
\end{tabular}

Printer-friendly Version

Interactive Discussion

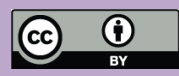




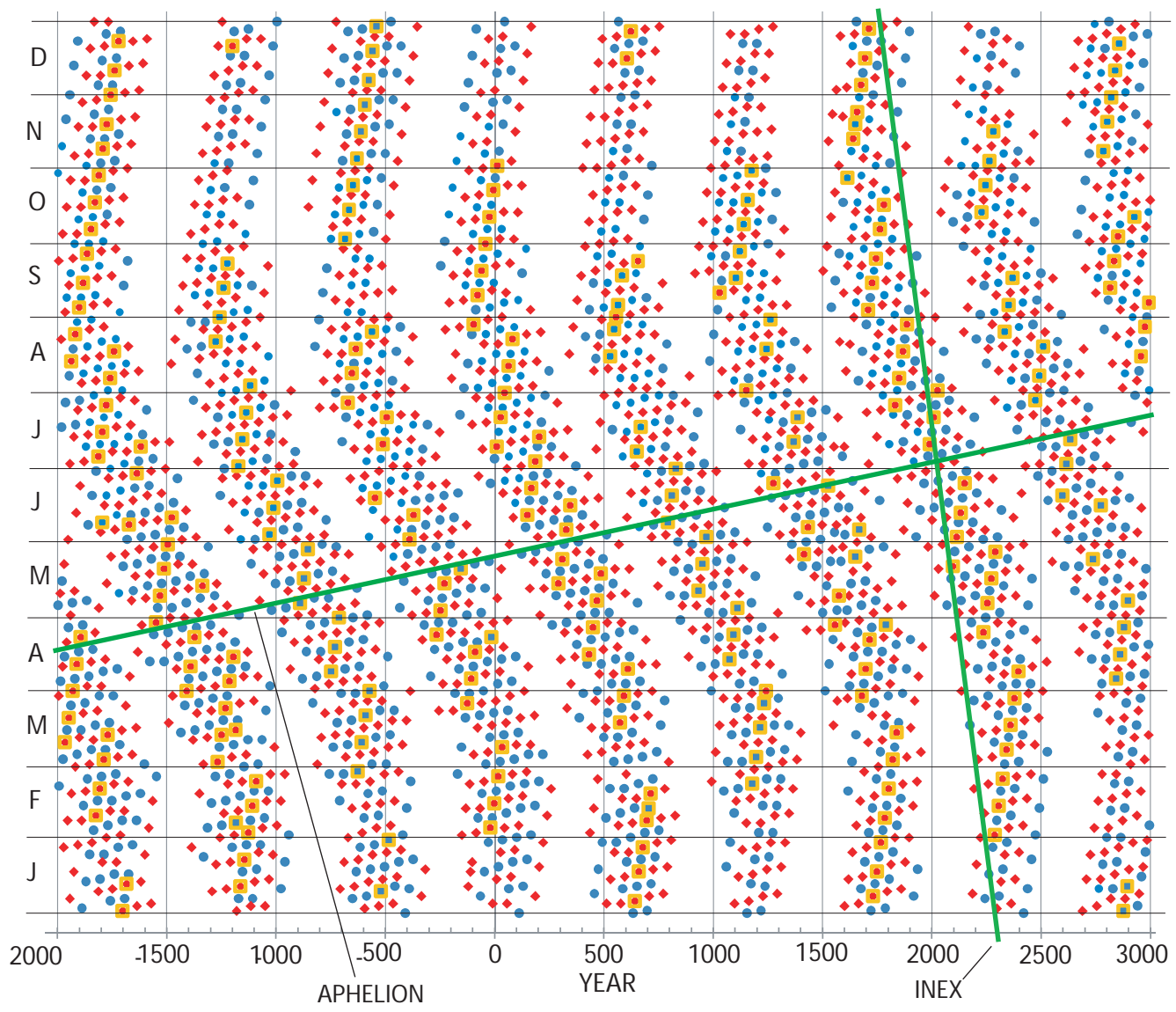

- LUNAR / SOLAR / LUNAR

口 PERIGEE (see text)

Fig. 13. -2000 to 3000 : 5 millennium day-year plot of LG event distribution (see text). Sources: Fred Espenak GSFC/NASA, John Walker Lunar Perigee and Apogee Calculator (www.fourmilab.ch/earthview/pacalc).

$6,905-961,2010$

\section{Global cooling by} equatorially

\section{symmetric La Niña}

J. H. Duke

\section{Title Page}

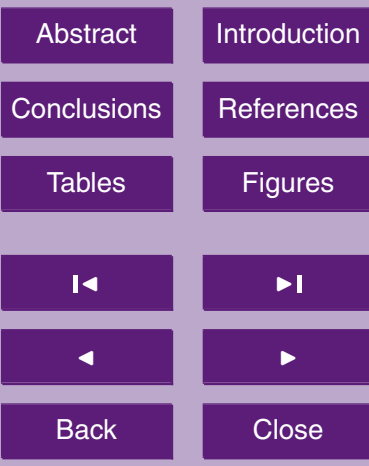

\section{Full Screen / Esc}

Printer-friendly Version

Interactive Discussion

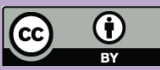




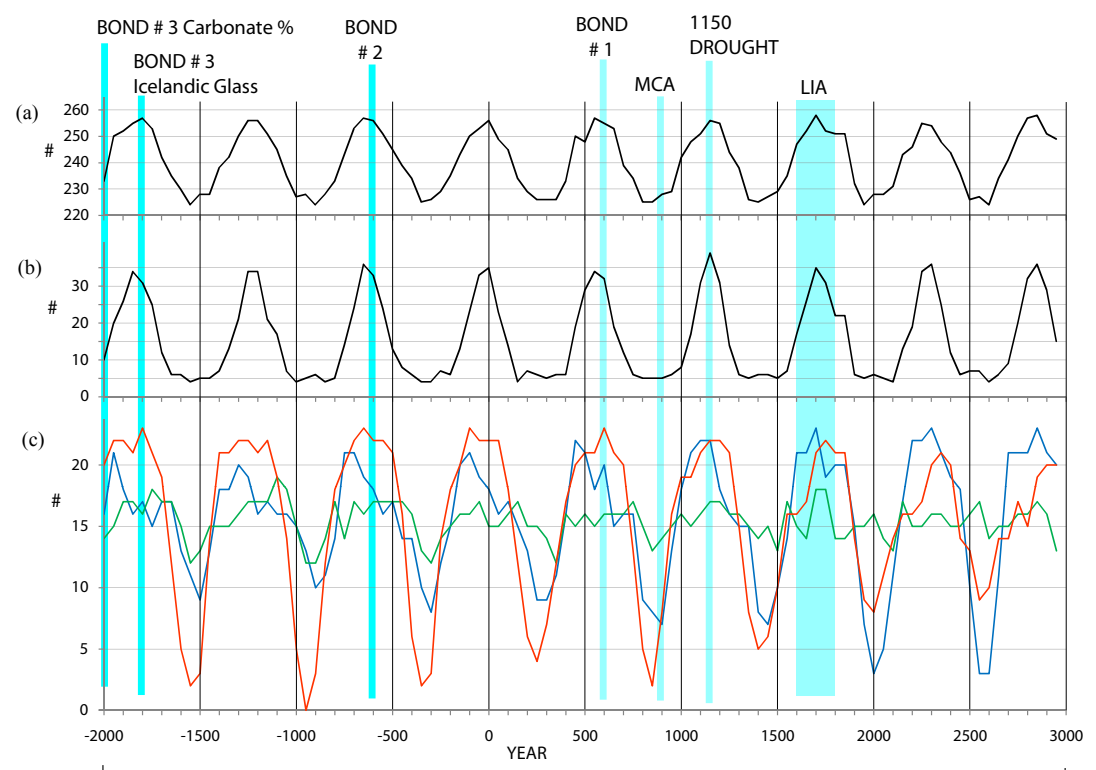

6, 905-961, 2010

\section{Global cooling by equatorially symmetric La Niña}

J. H. Duke

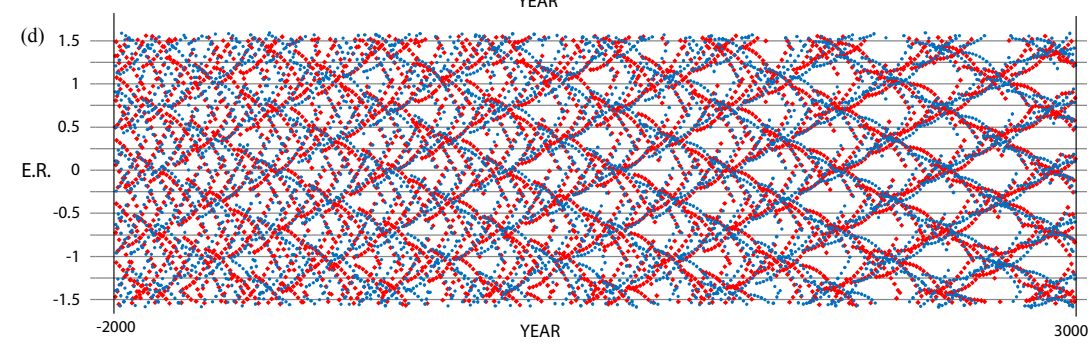

Fig. 14. -2000 to 3000 : Sum of eclipses within 50 years following date shown for (a) All gamma, (b) Absolute value of $\gamma<0.1$, (c) Absolute value of $\gamma<0.25$ differentiated by season \pm 75 days from 21 March (blue), 5 July (green), and 21 September (red), (d) Sequential gamma for all eclipses \pm 75 days from 21 March. Source: Fred Espenak, NASA/GSFC.

Title Page

\begin{tabular}{|c|c|}
\hline Abstract & Introduction \\
\hline Conclusions & References \\
\hline Tables & Figures \\
\hline I4 & $\bullet$ \\
\hline 4 & $\triangleright$ \\
\hline Back & Close \\
\hline Full Screen / Esc \\
\hline
\end{tabular}

Printer-friendly Version

Interactive Discussion

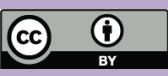



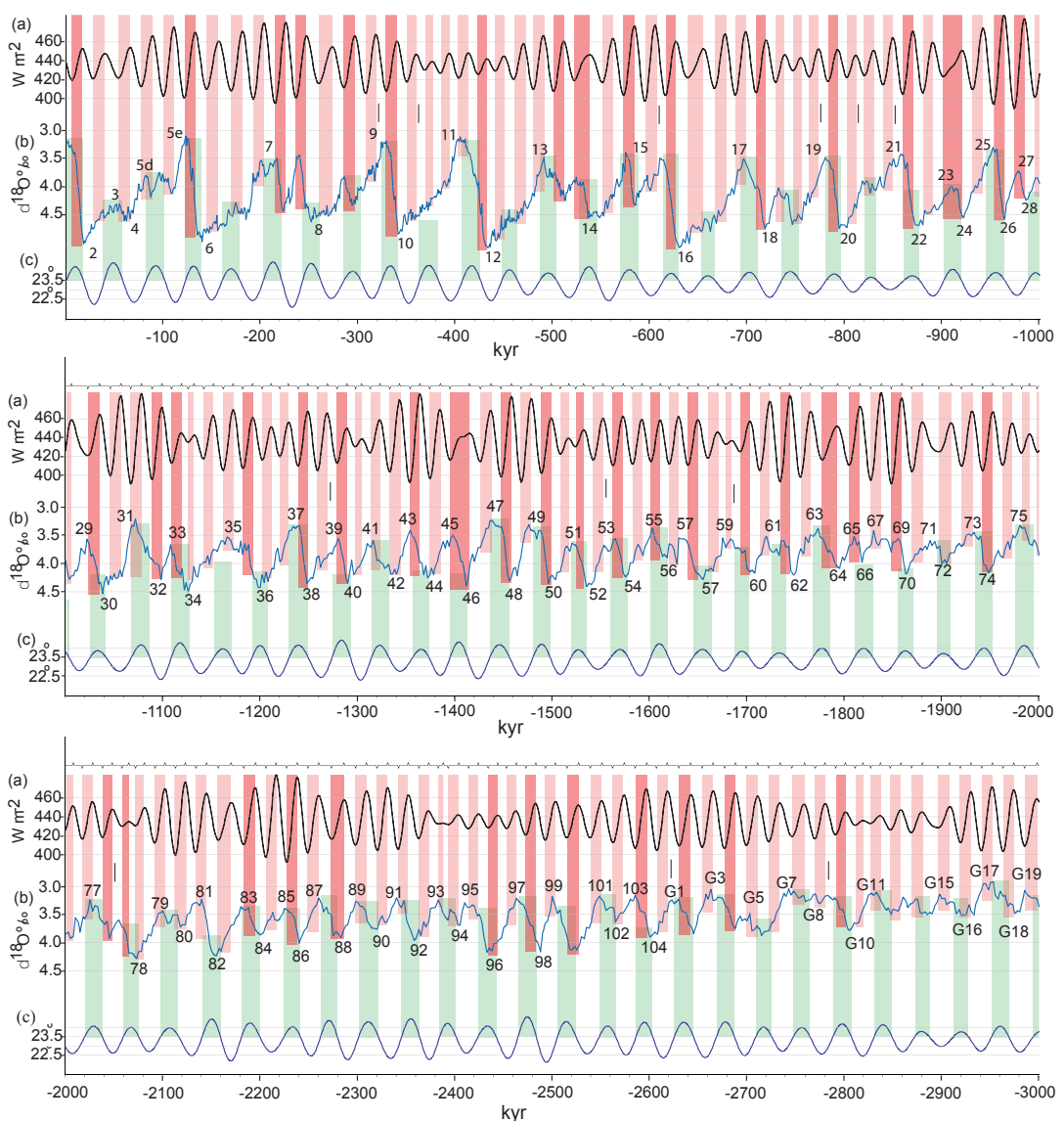

Fig. 15. 3 Ma to present: (a) Mid-month March insolation at equator; (b) d180 0/00; (c) Obliquity. Vertical red shading is between mid-month March perihelion and mid-month September perihelion. Vertical green shading is obliquity $>23.5^{\circ}$. Sources: Berger, 1978 , and Laskar, 2004; Lisiecki and Raymo, 2005; Berger, 1991.

\section{$6,905-961,2010$}

\section{Global cooling by equatorially symmetric La Niña}

J. H. Duke

\section{Title Page}

\begin{tabular}{|c|c|}
\hline Abstract & Introduction \\
\hline Conclusions & References \\
\hline Tables & Figures \\
\hline I & $\checkmark$ \\
\hline 4 & $\bullet$ \\
\hline Back & Close \\
\hline Full Screen / Esc \\
\hline
\end{tabular}

Printer-friendly Version

Interactive Discussion

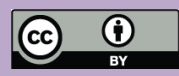

